\title{
Household Ethnoarchaeology and Social Action in a Megalith-Building Society in West Sumba, Indonesia
}

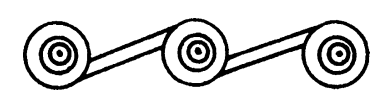

\author{
Ron L. Adams
}

\begin{abstract}
An analysis of contemporary megalith building, associated social endeavors, and material culture patterning among households in West Sumba, Indonesia can advance knowledge of the inner workings of past megalith building societies and how they can be identified archaeologically. As a reflection of broader sociopolitical dynamics, the household has become an essential unit of analysis in the examination of prehistoric social organization. This study of household ethnoarchaeology in West Sumba illustrates the utility of household-level analyses in the interpretation of megalith building societies of the ancient past. The results of household interviews and material culture inventories conducted in the Kodi area of West Sumba provide a nuanced view of the social entanglements linked to megaliths and related phenomena such as ritual feasting. A wide degree of interhousehold variability is associated with investments of resources into these endeavors in Kodi, reflecting not only the traditional means of achieving power and renown but also the traditional emphasis on group-oriented sociopolitical power and prestige. An examination of the household material culture linked to this behavior reveals both the potential insights as well as the limitations of inferring the intricacies of social action from material culture patterning. The results of this study can provide a useful interpretive model for megalith-building societies in appropriate contexts. KEYwORDs: ethnoarchaeology, megaliths, feasting, household archaeology, material culture, Indonesia.
\end{abstract}

StUdies in HOUSEHOld ARCHAEOlOgy HAVE LONG SOUght to decipher the functional aspects of households and how material culture patterning within the domestic sphere relates to broader social dynamics. In one of the early works in which household archaeology was conceptualized as a subfield of archeology, Wilk and Rathje (1982:618) championed the potential for analyses of household-level material culture patterning to bridge the gap between individual archaeological assemblages and "grand theories" of cultural processes. Indeed, various big picture social and cultural phenomena have been addressed through analyses of domestic material culture patterning in localized contexts, including but not limited to the division of labor, gender roles, social memory, cultural practice, the development of lineage-based societies, and early urbanism (Brumfiel and Robin 2008; Byrd 2000; Flannery and Winter 1976; Hodder and Cessford 2004; Müller et al. 2016; Tringham 1991). 
By offering insights into behavioral connections to house architecture and material culture patterning in living societies, ethnographic and ethnoarchaeological studies have consistently been utilized in these analyses of ancient households (Ashmore and Wilk 1988; Foster and Parker 2012; Wilk 1988; Wilk and Rathje 1982). Notable ethnoarchaeological examinations of house architecture include the work of Bowser and Patton (2004), who offered insights into gendered use of space within households, its potential archaeological correlates, and the different and complementary ways in which men and women engage in political practice. Lyons (2007) examined power relations in an analysis of vernacular architecture in the context of Tigray, Ethiopia, where sociopolitical power dynamics and inequalities are embodied and reproduced in the materiality of houses and through the process of their construction, following a pattern comparable to that associated with monument building. From a similar perspective, Kus and Raharijaona (2000) explored the symbolic layout of houses in the traditional kingdom of Imerina in Madagascar and how state ideology influences and is encoded within traditional house architecture.

Common among other examples of household ethnoarchaeology has been an emphasis on ascertaining inter-household variability in demographics, social standing, and wealth through patterning in household material culture and architecture. In an early example of household ethnoarchaeology, Kramer (1979) noted that while dwelling space was an accurate determinate of household population size, household wealth was correlated more with the size of house compounds and not necessarily with roofed dwelling spaces in a traditional Kurdish community in Iraq. Arthur (2009) more recently examined patterns of ceramic discard among the Gamo in Ethiopia and determined that the frequency of discarded vessels with long use lives, namely large storage pots, tended to correlate positively with household population size. Focusing more specifically on how inter-household social and economic factors relate to material culture patterning, Wilk (1983) surmised that values of community solidarity and equality were reflected in limited displays of wealth and standardization of household architecture among the modern Kekchi Maya. In highlighting the problems with focusing on household possessions alone, Kamp (2000) found that differences in household architecture were the most reliable indicators of household wealth disparities in rural eastern Syria and asserted more generally that architecture should be considered a more reliable indicator of wealth differentiation in an archaeological context than objects, given how patterns of discard, re-use, and recycling can displace items during their use-life cycles (Kramer 1979).

Extending beyond the categories of wealth, social standing, and demographics per se, household social behaviors, particularly those requiring excessive expenditures of resources, can shape household material culture assemblages. Ethnoarchaeological studies of the relationship between household possessions and wealth have shed light on how significant portions of a household's resources can be tied to social obligations, especially expenditures in ritual feasting events. In particular, household material culture related to feasting can be used as an indicator of behavior directly or indirectly linked to social status and wealth. Nelson (1981) found that factors related to social status, wealth, and the sponsorship of ritual feasts influenced the number and types of vessels that households owned in an ethnoarchaeological analysis of a highland Maya village. In an ethnoarchaeological study of household wealth and the ownership of cooking pots, Trostel (1994) observed that social obligations consisting primarily of events requiring livestock slaughter, such as funerals and marriages, constituted one 
of two primary uses of wealth (the other being "household maintenance") among the Kalinga in The Philippines. Elsewhere in Southeast Asian societies in which feasting figures prominently in traditional socio-political contexts, feasting material culture and its connection to household feasting behavior was a central focus of ethnoarchaeological studies in the Torajan highlands of Sulawesi Indonesia and in northern Thailand (Adams 2004; Clarke 2001).

The material remnants of household expressions of wealth and social prominence can also include megalithic monuments, which often encode power relations similar to what Lyons (2007) demonstrated for house architecture. Megalith-building in living societies has been shown to entail great expenditures of resources and large feasts in various traditional societies, particularly in Indonesia. Among these monumentbuilding locales, West Sumba arguably contains some of the most active traditional megalith-building/feasting complexes in the world, which are linked to the acquisition of power and the maintenance and advancement of important social networks.

\section{CONTEXTUALIZING MEGALITH BUILDING AND FEASTING IN WEST SUMBA}

The purpose of this study is to employ methods of household ethnoarchaeology in a megalith-building society in West Sumba to determine, first, whether household behavior in the related activities of megalithic tomb building and feasting can be ascertained through an examination of household material culture and architecture and, second, whether, by extension, these behaviors can be identifiable archaeologically. In West Sumba, significant material and social capital is expended on megalith building and feasting, both of which shape and maintain the traditional social order. Indeed, societies throughout island and mainland Southeast Asia are noted for their feasting events that in many cases drive social and political life (Hayden 2016). The ethnographic and ethnoarchaeological literature on Indonesian traditional societies has documented many such groups in which large stone monuments are built in connection with feasts of merit. In the Torajan highlands of South Sulawesi, for example, the erection of megalithic menhir monuments has traditionally constituted a prominent part of funeral feasts (Adams 2001; Crystal 1974). Large stone tombs and freestanding stones were, in the past, constructed within the ritual center of traditional villages in central Flores, just to the north of Sumba island (Arndt 1932; Forth 2001; Kusumawati 2002; Schröter 1998). Further westward in the Indonesian archipelago, a link between megalith building and feasts of merit can be found among the Batak of northern Sumatra and on Nias just off of the coast of western Sumatra, where large freestanding stone monuments were constructed (Barbier 1988; Beatty 1992; Feldman 1988; Sherman 1990). In northern Borneo, historical traditions of megalith-building and sponsoring feasts were associated with wealthy and high status individuals (Janowski 2003; Jones et al. 2016). In the more distant past, megaliths of various types were constructed throughout the Indonesian archipelago (Prasetyo 2013).

Temporally, current archaeological evidence suggests that the megalithic phenomenon in Indonesia occurred in the late first millennium to early second millennium A.D. (Steimer-Herbet 2018; Steimer-Herbet and Besse 2016). This time frame coincides with the late metal age of the region and into a protohistoric context when long-distance trade was increasing and Hindu-Buddhist kingdoms had begun emerging in the western part of the archipelago (Bellwood 2007). In one of the few anthropological archaeological investigations of megaliths in Indonesia, this pattern has 
been identified in the Jambi highlands of central Sumatra, where imported items such as glass beads, Chinese ceramics, and iron knives were found associated with megaliths dating to the period between the eleventh and thirteenth centuries A.D. During this time, the highlands likely maintained trade connections with the lowland Srivijaya kingdom of eastern Sumatra that was involved in trade with China, India, and the Arab world (Bonatz et al. 2006).

On the island of Sumba, the construction of large stone tombs appears to have commenced at a similar or even later time than the earliest megaliths in the central Sumatran highlands. While there has been no archaeological work on Sumba that has identified the origins of the current tomb-building tradition on the island, according to informants in traditional villages in West Sumba, the oldest tombs observed by the author range in age from 100 to more than 450 years old based on estimated genealogical time depths attributed to their construction (Adams 2007a:134). These age estimates are in line with legends in the oral history claiming that the noble classes on Sumba are descended from migrants who arrived on the island around the fifteenth century A.D., possibly from Java according to some oral accounts (Bühler 1951:57; Keers 1938:931; Needham 1960:257). This potential connection between Java and the noble classes on Sumba suggests that the tradition of megalith building could also have been brought to Sumba from Java, where monument building had long been prominent by that time period, although this notion requires further study.

An early to mid-second millennium A.D. time frame for the commencement of the current megalithic tradition on Sumba is also supported by archaeological evidence of an earlier burial tradition on the island that pre-dates the construction of stone dolmen tombs and could be an antecedent practice. The Melolo earthenware jar burial site in East Sumba, the largest and best known archaeological site on Sumba, has been dated to the Metal phase (500 B.C.-A.D.1000) of Island Southeast Asian prehistory based on the presence of metal artifacts and high-necked ceramic flasks characteristic of the period (Bellwood 2007:303-304; Soejono 1969:85; van Heekeren 1956). Ongoing archaeological research conducted by the Indonesian National Research Centre for Archaeology at the extensive jar burial site in Lambanapu near Waingapu in East Sumba indicates that this jar burial tradition on the island was in place by about 2500 years ago (Handini 2018).

\section{HISTORIC TO MODERN MEGALITH BUILDING AND FEASTING IN WEST SUMBA}

With apparent origins during the second millennium A.D., megalith building in West Sumba would have begun when the eastern Indonesian archipelago became increasingly linked to the wider world through trade. In the case of Sumba, these contacts would have been with the Javanese Hindu Majapahit empire of the fourteenth century A.D., as well as neighboring islands of Savu, Flores, and Sumbawa (Hoskins 1984:9; Kapita 1976:17). This trade reportedly brought iron, gold, beads, and Chinese ceramics to Sumba in exchange primarily for sandalwood and livestock (Hoskins 1984:9-11; Kapita 1976). By the sixteenth century A.D., European traders, namely the Portuguese and Dutch, stopped at Sumba to trade for such commodities as sandalwood and horses (Adams 2007a:54). Sumbanese slaves were also part of this global trade, leading to the intensification of an existing trade for slaves from the island and, according to oral accounts, an overall increase in internecine warfare on Sumba (Hoskins 1984:11; Kapita 1976:18; Kuipers 1990:17; Needham 1983). 


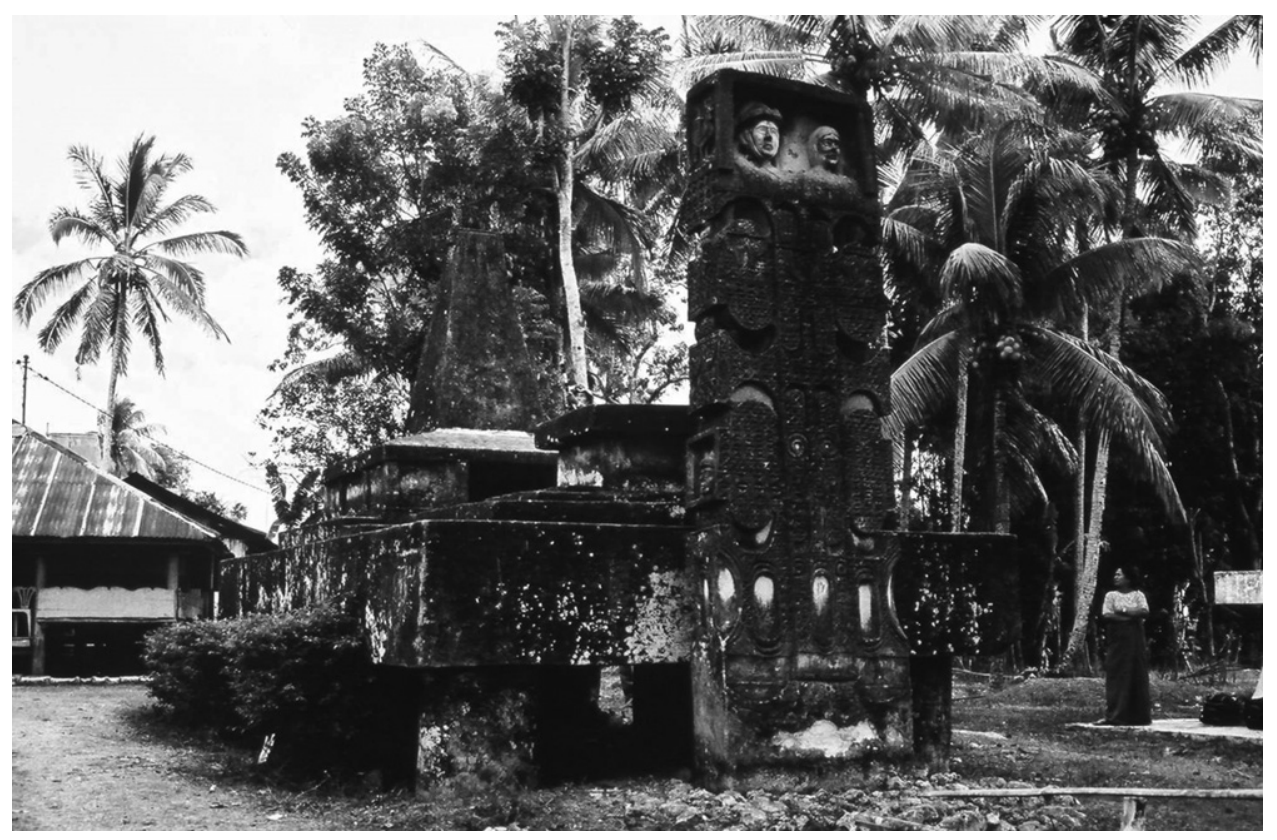

Fig. 1. Megalithic tomb in the Anakalang area of West Sumba, 2003. (Photo by Ron Adams.)

The antecedents of what would later become direct colonial administration of Sumba began in 1750, when the Dutch East India Company established exclusive trade with prominent rulers in East Sumba, who received weapons and luxury goods from the Dutch East India Company in return for establishing exclusive trade with the Dutch (Hoskins 1984:12, 13; Kapita 1976:21). From this time through the nineteenth century, Dutch interests were primarily in the eastern part of the island, and it was not until the beginning of the twentieth century that the Dutch began efforts at direct administrative control over West Sumba (Adams 2007a; Kapita 1976).

As a consequence of direct Dutch colonial control over West Sumba in the early twentieth century, slavery became officially outlawed and more formal administrative districts were created that were based on traditional linguistic boundaries and included many clans, which were traditionally at the highest level of formal socio-political organization. Rulers known as raja administered these areas, although the power of a raja was limited if they were not existing authority figures in the traditional context of socio-political power based on clan groups (Djakababa 2002:45-46; Groeneveld 1931:13-14; Koike 1986:8). Tax collection was also introduced by this time, which drove many to the cash economy who were otherwise tied to a barter system (Vel 2008:26). However, by all accounts, traditions of feasting and tomb building flourished during this time in spite of these changes. The intensity of these traditions in fact appears to have increased as ways to achieve power and renown after the Dutch outlawed headhunting and internal warfare, which had been other avenues through which power and competition were negotiated in previous times (Hoskins 1989).

The socio-political organization of Sumba was once again altered to fit the Indonesian system of districts and regencies after Indonesia gained independence in 1949. Individuals in West Sumba who became wealthy through non-traditional means 
(e.g., modern commerce, educational opportunities) in this context were able to sponsor traditional feasts and tomb building as a way of gaining renown and support for modern political positions (Hoskins 1984:26, 27). This pattern has persisted into the beginning of the twenty-first century and tomb building and related traditional feasts remain very active in parts of West Sumba (Adams 2007a:205, 206; Vel 2008:70-73).

Ethnographic and ethnoarchaeological documentation of these extant traditions of stone tomb building and feasting in West Sumba has illuminated some of the broad sociopolitical aspects of the practice. In particular, the link between these endeavors and social status and the achievement of sociopolitical power and renown has been well documented (Adams 2010; Hoskins 1984; Kusumawati 1997, 1998, 2000). The obvious material manifestation of this practice is the presence of the tombs, which can be large dolmen monuments made of limestone with combined tombstone weights of well over 60 metric tonnes (Fig. 1). What is less obvious is the inter-household variability associated with participation in megalithic tomb building and how it relates to other aspects of traditional sociopolitical and economic dynamics. This study aims to explore the dynamics of social action among households in West Sumba by examining the inter-related realms of megalith building, feasting, and marriage expenses, and how these aspects of social action may be reflected in material culture.

\section{HOUSEHOLD ANALYSIS}

Field data from individual households in this study were collected in West Sumba as part of the Ethnoarchaeology of Southeast Asian Feasting Project directed by Brian Hayden of Simon Fraser University. The bulk of the data presented in this article was collected from ethnoarchaeological research conducted by Ron Adams in collaboration with Ayu Kusumawati of Balai Arkeologi Denpasar (Indonesia) and Haris Sukendar of

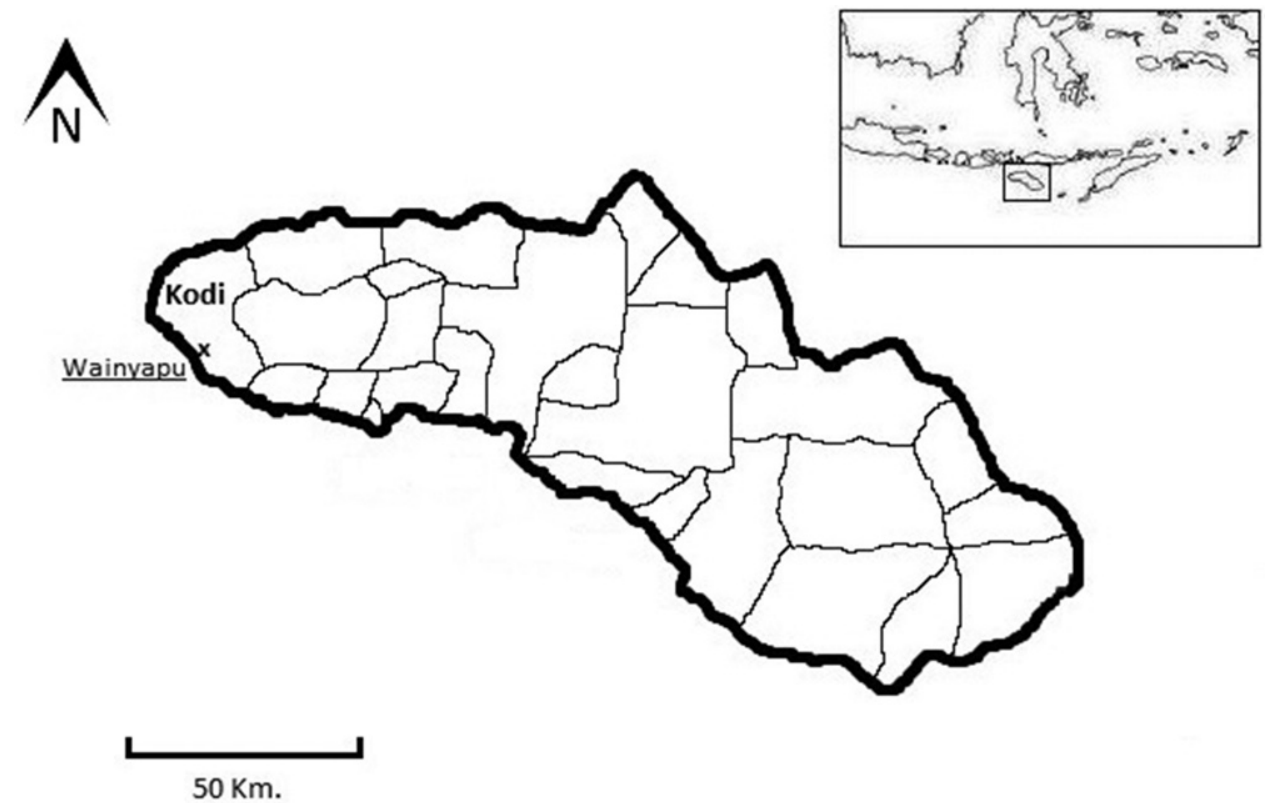

Fig. 2. Map of Sumba showing location of Wainyapu village in Kodi. 
the Indonesian National Research Centre for Archaeology in 2003. Preliminary ethnoarchaeological fieldwork on tomb building in West Sumba was conducted as part of a field study project undertaken by Adams in collaboration with Stanislaus Sandarupa of Universitas Hasanuddin (Indonesia) in 2001. Unless cited otherwise, the data presented in this paper are derived from Adams' (2007a) doctoral thesis (Simon Fraser University).

In this analysis, I present data collected from 25 households interviewed in the traditional domain of Kodi at the far western end of Sumba, where the practice of tomb building has remained active and socially relevant (Fig. 2). The household surveys included standardized interviews of household members (typically the patriarchal male head of the household) and documentation and mapping of household architecture and material culture (with permission from the household). Information gathered in household surveys pertained to the socioeconomic standing of households, household demographics, the material culture of households, household marriage status and marriage expenses, and household participation in tomb building and feasting. Analyses of these data are presented in the sections that follow.

\section{Households}

Households comprise the most basic unit of sociopolitical organization in West Sumba, representing the nuclei of families' economic activities. Individuals comprising a household typically include a married couple, their unmarried offspring, elderly parents, and sometimes grandchildren. Among households surveyed for this study, a range of between 2 and 17 family members resided in each household, with a mean of just under 7 and a median household size of 6 individuals.

A household group is associated with one or more domestic structures. For example, a household residing in a house in an ancestral village may also have a house in a hamlet outside the village that is closer to cultivated lands or modern roads. At times, these secondary houses are occupied by adult sons of the household head. Architecturally, houses in West Sumba are traditionally constructed with a combination of large wooden posts, bamboo, and grasses. A house typically contains a bamboo floor raised between approximately one and two meters above the ground surface (Waterson 1990) (Fig. 3). Domesticated animals are kept underneath the bamboo floor, while rice and sacred ritual objects are stored on platforms below the roof.

Households in West Sumba are organized into patrilineally-based ancestral house groups referred to as uma that contain many features typically associated with sociétés à maison (house societies) in the anthropological literature (Adams 2007b; Gillespie 2000; Lévi-Strauss 1983). Each uma contains numerous attached households and is represented by a single, named ancestral house. The household residing in the main house of an uma acts as a custodian of the ancestral house structure but is not necessarily the most politically prominent or wealthy household in the ancestral house group. This is an important point in the context of this study and other household studies involving corporate houses, as the architecture of a house can be more reflective of a larger group as opposed to the individual household residing in the structure at a given time.

Numerous households are attached to each uma and groups of related uma comprise an exogamous clan group (parona). The ancestral houses of these uma, the major branch houses of the ancestral houses (known as uma karekatena), and sometimes one or more common houses (referred to as rumah kebun or "garden houses") are situated in clan 


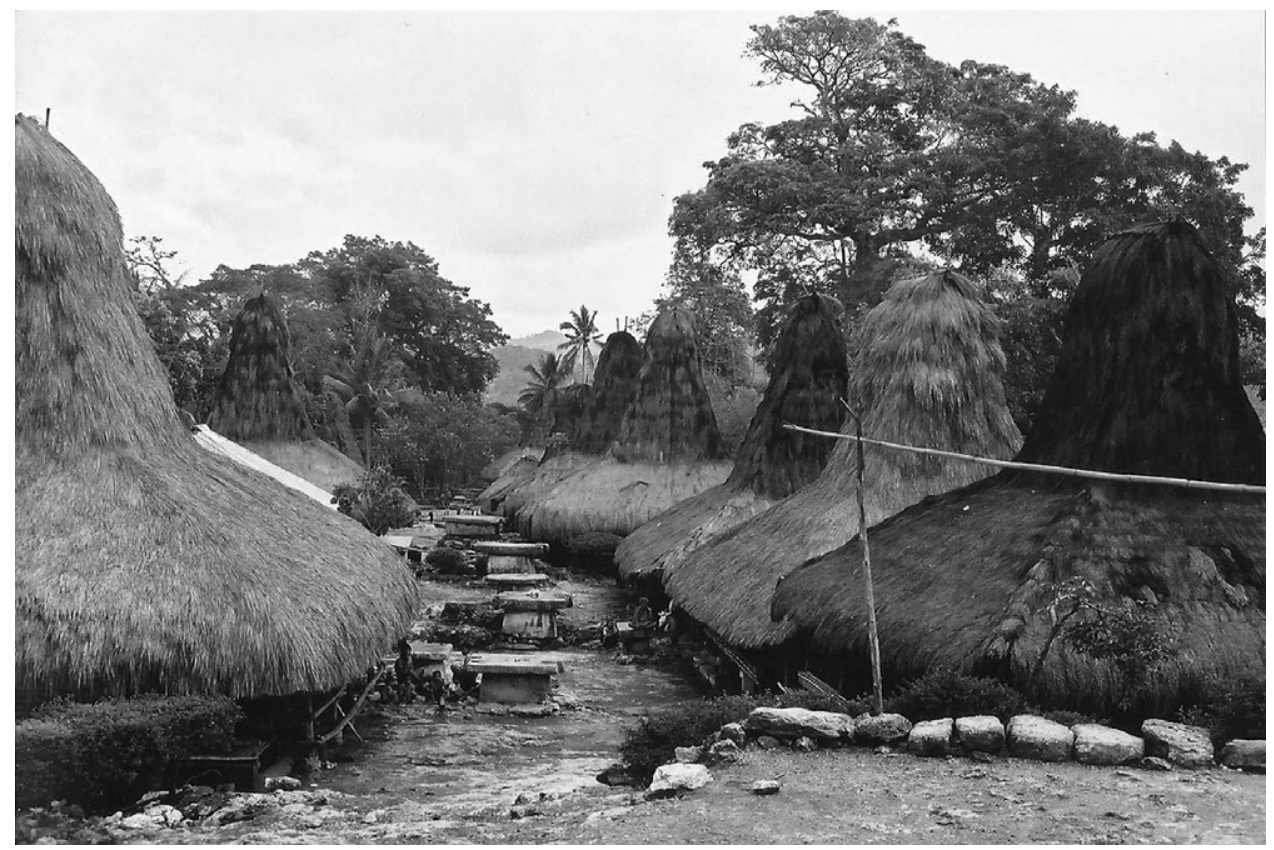

Fig. 3. Traditional houses in West Sumba, 2003. (Photo by Ron Adams.)

ancestral villages. The ancestral houses and branch ancestral houses comprise the core of the ancestral villages and encircle the ceremonial feasting plaza (natara) of the clan and the megalithic tombs surrounding the natara. Several small hamlet communities affiliated with the clans are usually located up to several kilometers away from the ancestral villages.

The majority $(n=22)$ of the households analyzed for the current study were located in clan ancestral villages within Wainyapu, a mega village consisting of a cluster of ancestral villages representing 12 clans. Two of the households surveyed were affiliated with Wainyapu clans but were located in communities outside of Wainyapu; another household resided in the clan ancestral village of Ratenggaro, a stand-alone ancestral village near Wainyapu that is associated with the Ratenggaro clan.

Because these clans and smaller uma groups are patrilineal and associated with patrilocal residency, this study has an inherent bias towards the male household heads who act as the official sponsors of tomb building, feasts, and other political endeavors associated with the named clan with which he is affiliated. Matrilineal relations are also recognized; while not as outwardly political on the surface, they are significant and can be associated with important political and economic support networks (Hoskins 1984). Although the subject of how gender relates to the nuances of everyday power dynamics is beyond the scope of the current study, the role of women as political actors in West Sumba should not be dismissed. For example, the first wife of a household head (who lived in another village with his second wife) managed a household in Wainyapu and participated in undertakings within the village, such as directing labor during a tombstone dragging episode, apparently with considerable autonomy. Furthermore, while tombs are associated with the male household heads who sponsor their construction, deceased wives of the household heads are also interred in these 
tombs. Thus, to avoid assumptions about power within households, when discussing sponsors of tomb building and other endeavors, I am referring to the household as a whole, even though the name usually attached to the sponsoring role is that of a patriarchal household head.

\section{Tomb Building Sponsorship}

Sponsoring the construction of a tomb in West Sumba can be associated with high costs of labor and resources. Those who sponsor (i.e., the main provider of resources for the endeavor) tomb building are either building a tomb for themselves or a diseased parent or grandparent who was not able to build a stone tomb in their lifetime. After being constructed, several individuals can be interred in the tomb, including the deceased married couple and their grandchildren, but not their own children. Thus, there is a limited degree of collective burials associated with tombs in Kodi, although it is considered more desirable for each generation to build their own tomb (Jeunesse and Denaire 2018).

The costs, in terms of labor, time, and resources, associated with the sponsorship of tomb building can be excessive. In the most extravagant cases, the processes from quarrying to the final assembly of the tomb can take over a month to complete and require the labor of more than 1000 individuals to haul the stone across the landscape; more than 50 water buffaloes and 50 pigs may be sacrificed at feasts held to feed the workers and others invited to partake in each stage of tomb building. For example, Figure 4 depicts the pulling of a moderately-sized capstone weighing approximately 10 tonnes; 1000 people were invited to haul the stone for one day and the work feast

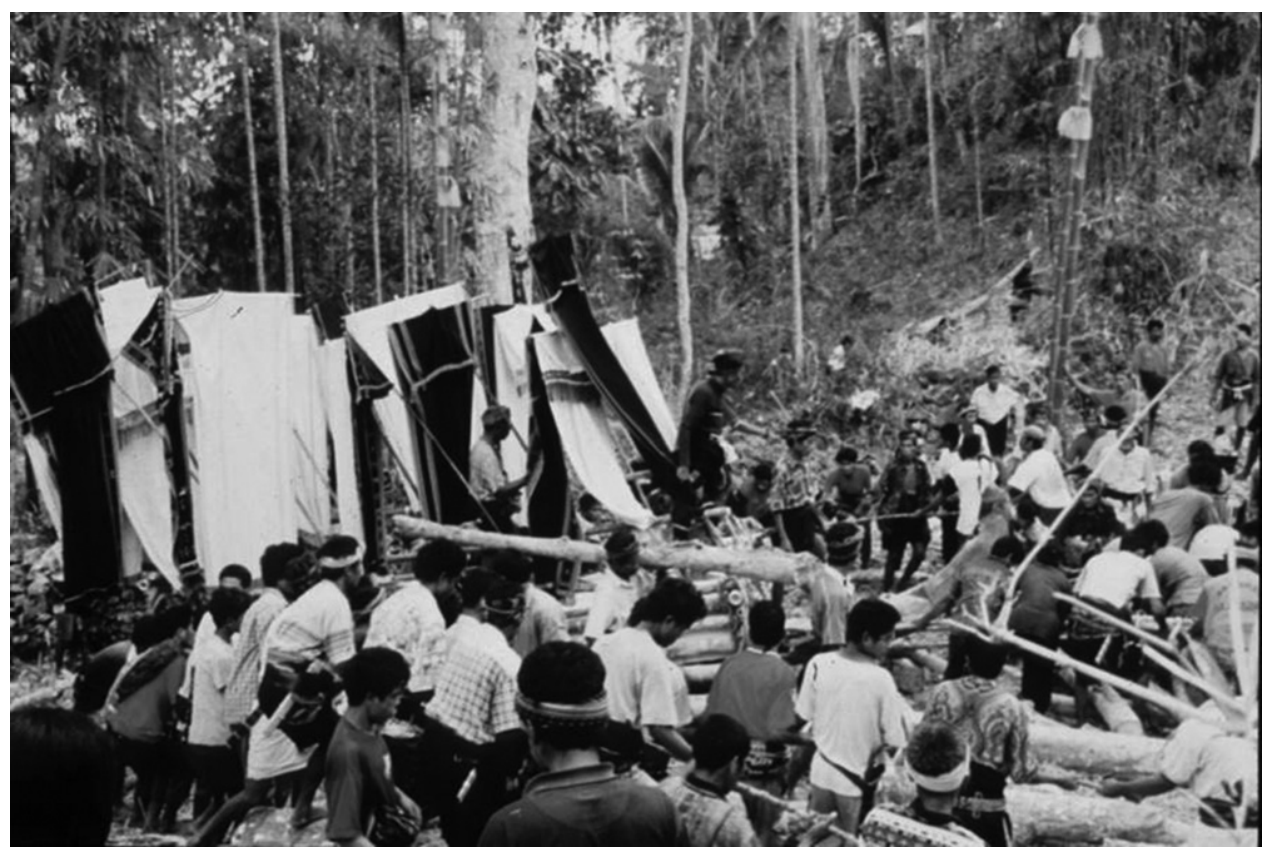

Fig. 4. Hauling a large capstone for a tomb in Anakalang, West Sumba, 2003. (Photo by Ron Adams.) 


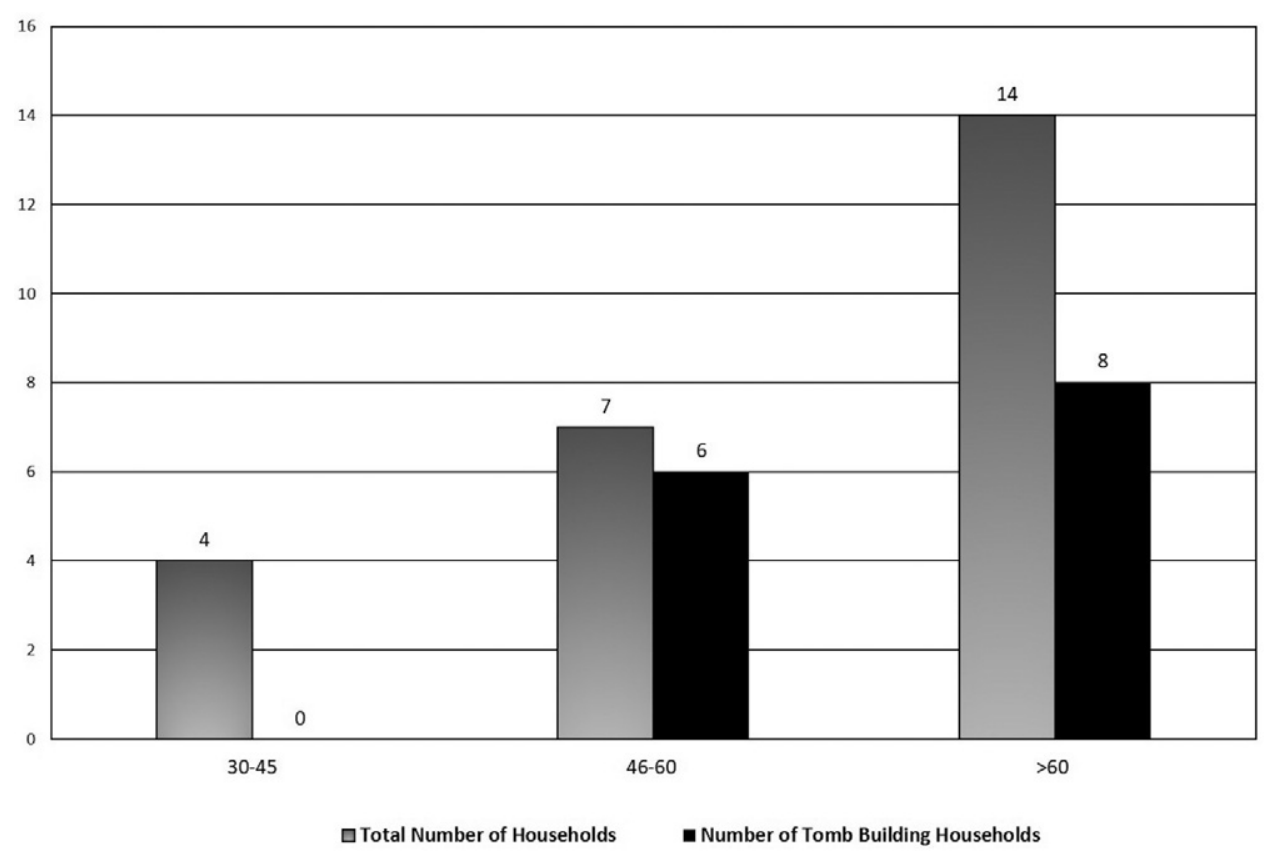

Fig. 5. Bar chart illustrating frequency of tomb-building household heads in different age-range categories.

entailed the slaughter of 1 water buffalo and 11 pigs. Because of the planning and interpersonal networking involved, only well-established households tend to sponsor tomb construction.

Sponsoring the construction of a stone tomb, in addition to sponsoring a series of other large feasts and a bride-price payment, is considered a requisite milestone for attaining the traditional status of a rato in Kodi. Being a rato entailed access to the inner circle of power within a clan group (Hoskins 1984). Even in the modern context, sociopolitical power and influence are associated with this achieved status. Thus, one of the central issues addressed from the household survey data was the degree to which tomb building could be empirically linked to wealth and renown.

Among the households represented in this study, 14 claimed to have sponsored the construction of a stone tomb. This number seems high considering the costs that can be associated with tomb building and its connection to traditional power. When dividing households into age-grade categories, some patterning emerges (Fig. 5). All 14 of the household heads who can be classified as tomb builders were over the age of 45 at the time of the survey. Within the age-grade categories, the highest concentration of tomb-building households ( 6 of the 7 households represented) were headed by people between the ages of 46 and 60 . The remainder were over 60 years of age or deceased, in which case the widow was the living head of household. Overall, more than half of the household heads interviewed $(n=14)$ were over 60 years of age.

The paucity of younger household heads in this study is likely attributable to a combination of changing residential patterns and the fact that more senior clan members traditionally occupy the uma houses within ancestral villages. Younger clan members tend to live in traditional hamlets, recently established settlements adjacent to 
modern roads, or modern towns within and outside of the local area. Thus, in the general population, the proportion of households that have sponsored the construction of a stone tomb is most likely considerably lower than in the sample presented here. On the other hand, the absence of younger tomb-building households does not necessarily point to a decline in the practice of tomb building, as more established households are expected to have had the time to accumulate the resources and build up the relationships required for sponsoring tomb construction.

Furthermore, a high proportion of stone tombs in Wainyapu appear to have been built relatively recently. For example, more than half of the tombs ( $n=15$ out of 24 tombs) in the Wainjolo Wawa clan section of the village had been built no more than 30 years prior to the time of fieldwork. This increase in the frequency of tomb building in recent times is likely attributable to the adoption of modern methods for transporting stones (including truck transport) and the use of cheaper materials such as cement. It is not possible to determine whether this trend will continue into the future based on the small sample $(n=3)$ of household heads in this study that were under the age of 45 at the time of this survey. However, it is worth noting that one of these younger household heads was planning on building a tomb in the future.

\section{THE RENOWN AND WEALTH OF TOMB BUILDERS}

One of the key issues of this study was to determine whether there was a correlation between household socioeconomic standing and the sponsorship of tomb construction. As noted previously, tomb building is associated with the achievement of traditional modes of power. Establishing a verifiable link between tomb building and social renown in the modern context would help explain the persistence of the practice and its practical relevance. In this study, household wealth is assumed indicative of renown.

Social standing and power within a clan group is traditionally linked to tomb building and the sponsorship of feasting endeavors. While the households surveyed were solidly living in the modern world with access or at least knowledge of the amenities of the twenty-first century at the time of this study, traditional practices of tomb building and feasting remained a significant feature of the social landscape. Given its apparent ongoing relationship with sociopolitical standing, wealth was expected to correlate positively with tomb building among these households.

\section{Tomb Building and Household Wealth}

Household wealth in a traditional subsistence-based agrarian economy is difficult to quantify. In order to gain an approximation of the wealth differences between households, a household wealth index was created that translated livestock holdings, yearly rice harvests, cash crop harvests, and any cash income into a cash value estimating a hypothetical yearly cash income a household could garner in a given year (i.e., potential yearly household income). Similar approaches to estimating household wealth in traditional societies have been used for many years in ethnoarchaeological studies (Kramer 1979; Trostel 1994). These wealth estimates are not considered an accurate depiction of household wealth in absolute terms. They were instead created to measure the relative wealth variability between surveyed households. Households that were headed by elderly widows were removed from these analyses comparing wealth 


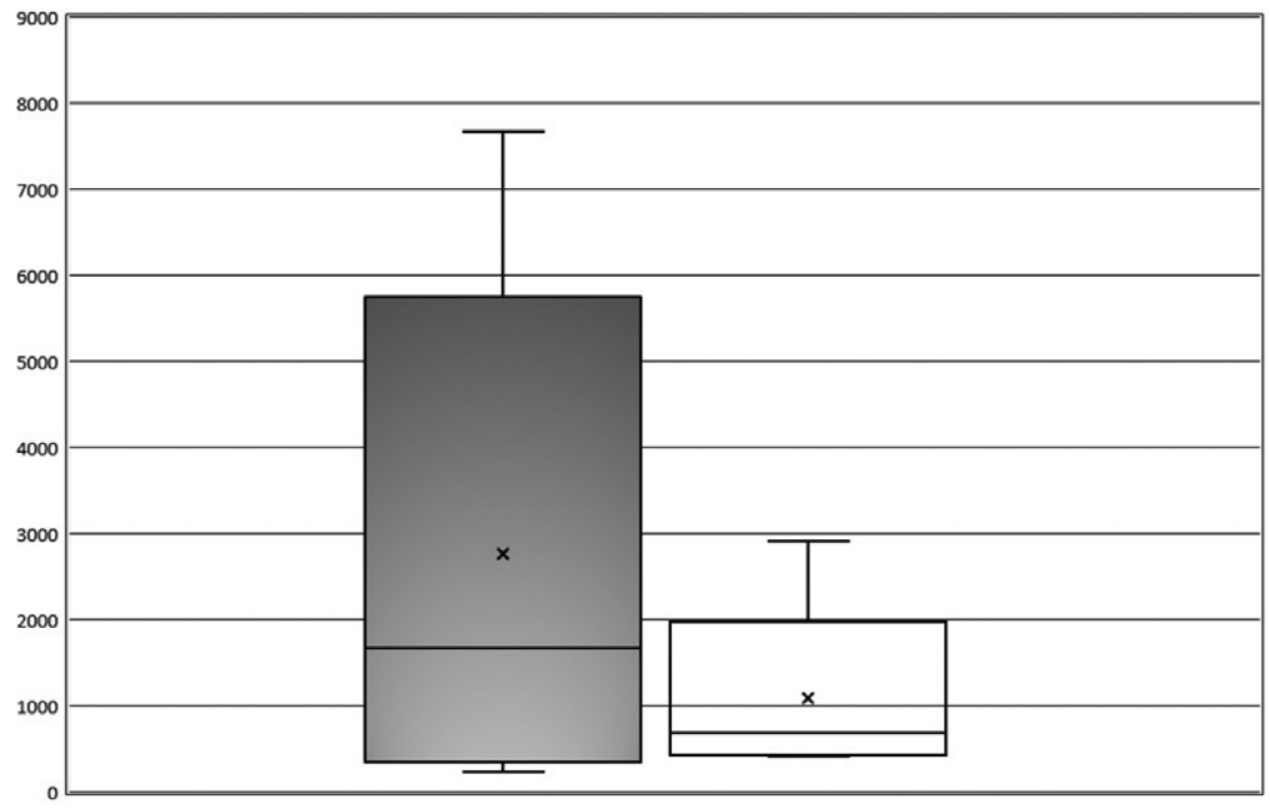

$\square$ Households that have built a tomb $\square$ Households that have not built a tomb

Fig. 6. Box plot of relationship between megalithic tomb building and household income.

to tomb building, because the economic status of the household at the time of the interview would not have adequately depicted the status of the household during the time its patriarchal head was still alive.

A comparison of households that had previously sponsored the construction of a tomb with those that had not (tomb-building vs. non-tomb-building households) indicates that tomb-building households tended to be wealthier than non-tombbuilding households (Fig. 6). However, after comparing tomb building and household wealth using a Yates continuity correction cross-tabulation $\chi^{2}(.05$ level of significance; $\mathrm{Df}=1$ ) test with two wealth categories (households with estimated potential annual incomes of less than US $\$ 1200$ dollars and households with estimated potential annual incomes of US $\$ 1200$ dollars or greater) compared against the two categories of tomb-building vs. non-tomb-building households, this difference was found to be statistically insignificant $\left(\chi^{2}=1.97\right)$. This lack of strong correspondence was partially attributed to the presence of one wealthier household among the non-tomb-building households. However, this recently established wealthier household was planning to build a tomb in the future.

In addition, there were several poorer households in the tomb-building household category. The presence of these poorer households in the tomb-building category is likely attributable to two primary factors: (1) the lower costs associated with modern methods of tomb building; and (2) inter-household support within clans. Some tombbuilders use bricks and cement to build tomb walls and trucks to transport large capstones. Both of these innovations are less labor intensive than traditional methods of 


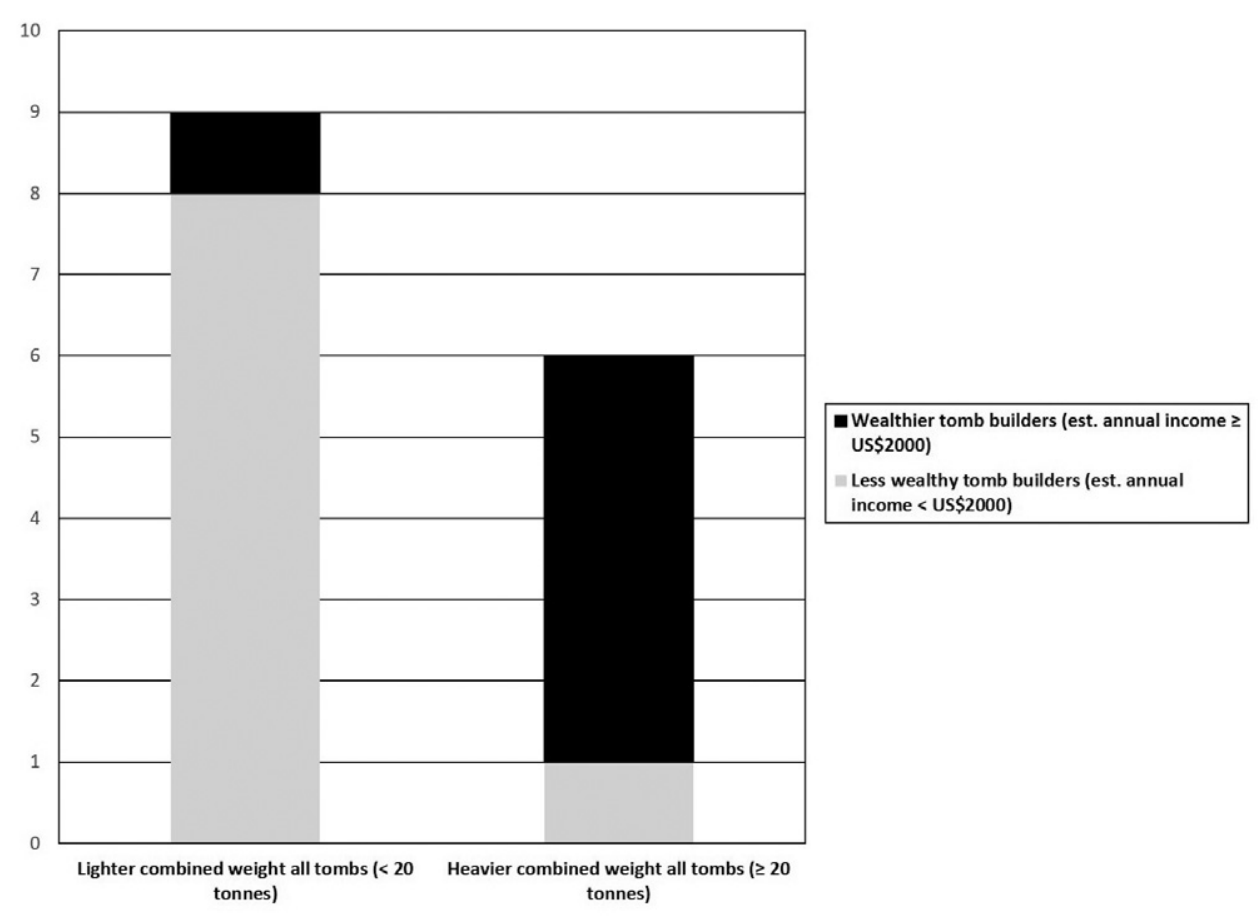

Fig. 7. Bar chart illustrating relationship between megalithic tomb weight and household wealth.

quarrying and tombstone transport and therefore lessen the costs of financing tomb building work feasts. With regard to inter-household support, some informants expressed a desire to assist fellow clan members with tomb-building costs, as the tombs convey prestige upon not only the primary sponsors or tomb builders but also collective prestige upon the clan as a whole.

When comparing tomb size (combined weight of all tombs built by a household) to indices of household wealth, there is a strong positive correlation between household wealth and estimated combined weights of tombs based on their approximate sizes (in metric tonnes). Wealthier tomb-building households tended to build larger tombs and more tombs overall than poorer tomb-building households (Fig. 7). Indeed, larger tombs are said to confer a greater amount of prestige on the tomb builder and the tomb builder's clan compared to smaller tombs. Building multiple tombs, for example when a household builds a tomb for their deceased parents or grandparents in addition to their own tomb, also confers such prestige. A Yates continuity correction crosstabulation $\chi^{2}(.05$ level of significance; $\mathrm{Df}=1)$ test with two wealth categories (tombbuilding households with estimated potential annual incomes of less than US $\$ 2000$ and tomb-building households with estimated potential annual incomes of US $\$ 2000$ dollars or greater) compared against tomb size categories (combined tomb weights of less than 20 tonnes and combined tomb weights of 20 tonnes or heavier) indicates that the correlation between the magnitude of household tomb building and household wealth is statistically significant $\left(\chi^{2}=3.98\right)$. 


\section{Tomb Building and Social Interconnectedness}

In the traditional clan-based societies of West Sumba, wealth alone does not translate into power and renown. The degree to which one is well-connected both within and outside of one's clan is also considered key to attracting a large following and gaining power and renown within one's clan group. Two measurable indices of a household's sociopolitical network are feasting and the sponsorship of marriage bride-price or return bride-price payments.

Feasts throughout West Sumba are associated with obligations of providing livestock or other items for feasts hosted by other households. These contributions must be repaid by the recipient household on a feasting occasion at a later time. The degree to which one household participates and invests in feasting is a good indicator of the extent of its connections with other households both within and outside their clan.

Feasting contributions in West Sumba are often associated with affinal obligations, and the establishment of these relations through marriage entails similarly high livestock costs for bride-price and return bride-price payments. In Kodi, bride-price payments can range from ten heads of livestock (five horses and five water buffaloes) to 100 heads of livestock (50 horses and 50 water buffaloes), in addition to varying numbers of gold prestige items. The return bride-price payments can range from two pigs to five large water buffaloes, as well as up to 40 pieces of finely woven cloth. Marriages involving wealthy and influential families typically entail the highest brideprice and return bride-price costs.

In most cases, bride-price and return bride-price payments in Kodi are sponsored by the parents of the bride and groom respectively. As the primary sponsor, these households are required to contribute at least 30 percent of the expenses related to the bride-price or return bride-price. Other close family members, fellow clan members, and trusted friends also contribute to marriage expenses. These marriages typically continue an established wife-giver to wife-taker relationship between two clans that spans generations. The connections between wife-giver and wife-taker clans are continually expressed on feasting occasions in which wife-taker clans are obligated to contribute water buffaloes to feasts held by wife-giver clans and wife-giver clans are obligated to contribute pigs and finely woven cloth to large feasts held by wife-taker clans in return.

In soliciting information regarding investments in feasting and marriage-related sponsorship, details of investments for feasts held and attended and the household sponsorship of marriages over the past ten years were gathered from the household surveys. Resource investments in feasting and marriage-related sponsorship typically entailed livestock contributions; for purposes of comparison and quantification, investments in livestock are the focus of this discussion.

A comparison of tomb building with investments in both feasting (excluding those associated with building tombs) and marriage-related costs reveal relatively strong positive correlations. Households that had built a tomb in the past reported higher bride-price payments for both their own marriages and those of their offspring (i.e., the bride-price payments paid on behalf of sons and the bride-price payments received from daughters' marriages) in comparison to the bride-price payments associated with households that had not built a tomb. This variance was determined to be statistically significant according to a $T$-test $(\mathrm{Df}=21 ; t$ Stat $=3.29 ; t$ Critical two-tail $=2.08)$ (Fig. 8). In terms of feasting, tomb-building households tended to invest more in 
Bride-price expenses (heads of livestock)

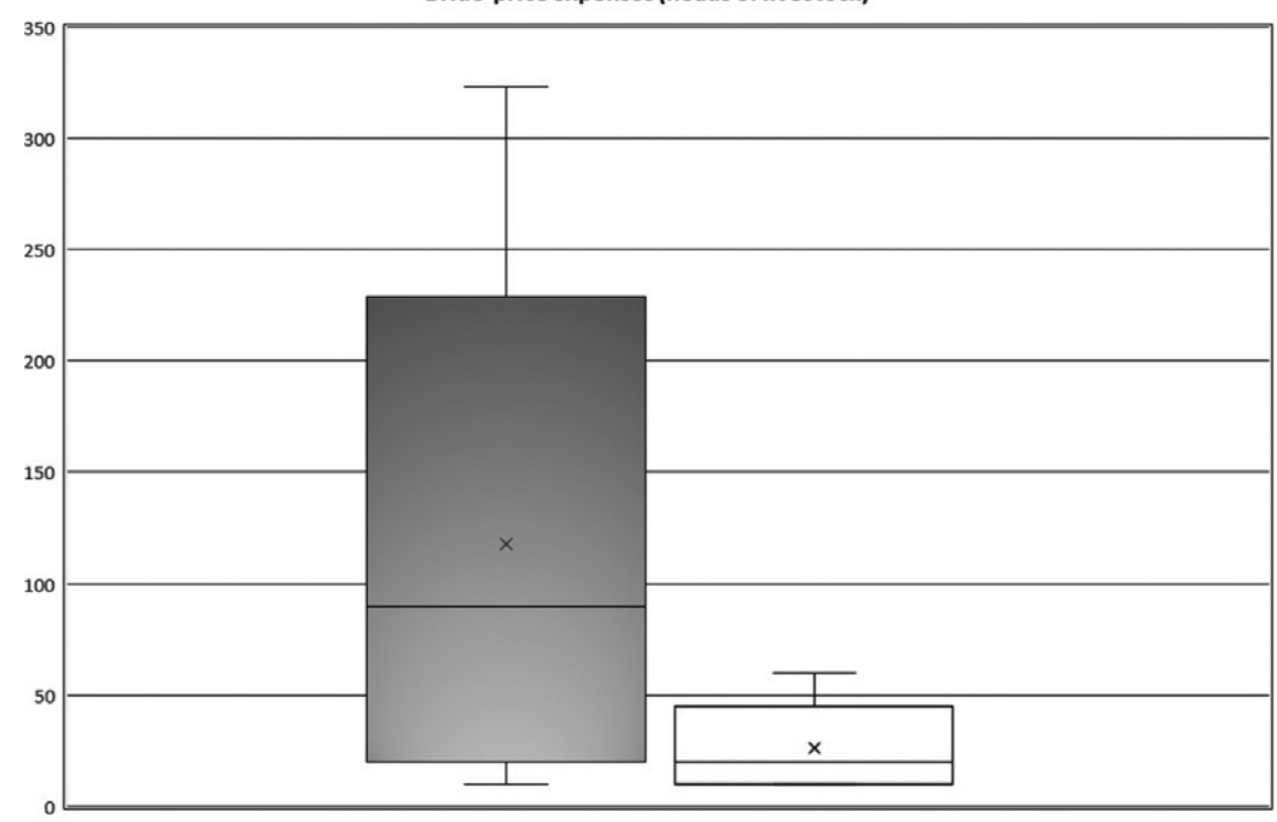

$\square$ Households that have built a tomb $\square$ Households that have not built a tomb

Fig. 8. Box plot of relationship between megalithic tomb building and total bride-price expenditures, with bride-prices for marriages of household heads and their offspring calculated in heads of livestock.

feasting (combining feasts attended and feasts hosted) than non-tomb-building households. This difference in feasting investments was found to be statistically significant according to a Yates continuity correction cross-tabulation $\chi^{2}$ (.05 level of significance; $\mathrm{Df}=1)$ test with the categories of tomb-building and non-tomb-building households compared against the categories of households that had contributed more than five heads of livestock for feasts in the past ten years and households that had contributed five or fewer heads of livestock for feasts in the past ten years $\left(\chi^{2}=5.81\right)$. These data do not include feasts associated with tomb-building, which would bias the comparison. Illustrating the link between inter-connectedness and tomb-building even further, tomb-building households also tend to invest more than non-tomb households in feasts held in other clans. Such contributions to feasts hosted by other clans are typically obligations associated with wife-giver to wife-taker relations.

\section{HOUSEHOLD MATERIAL CULTURE}

House maps and inventories of household material culture were created for households residing in the village of Wainyapu (22 of the 25 households surveyed in Kodi). The inventories and maps were completed with permission from the heads of households and consisted of counts of items related to food serving and food-preparation, as these are the items of everyday material culture that would most likely be associated with tomb building, given the large amount of feasting activity associated with the practice. The ownership of prestige items such as gold ornaments could potentially offer insights 


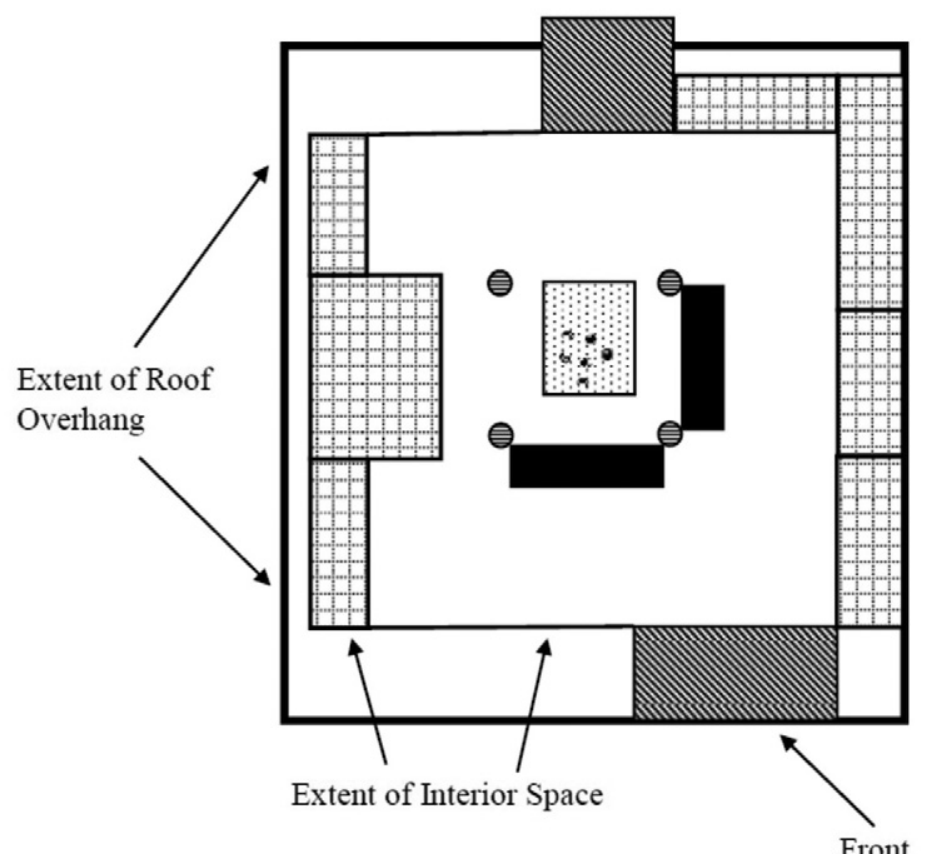

\begin{tabular}{|c|c|}
\hline \multicolumn{2}{|l|}{ Legend } \\
\hline Sleeping Room $\square$ & Hearth $\square$ \\
\hline Hearth Stone & Veranda $\mathbb{N}$ \\
\hline Shelf/Bench & Central Post $\mathrm{E}$ \\
\hline
\end{tabular}

Veranda/Entrance

Fig. 9. Map of interior of house in the Kaha Malagho clan section of Wainyapu.

into tomb building and feasting behavior, as their display can be associated with large feasts. However, soliciting information regarding the ownership of these types of items was considered invasive due to theft concerns. Likewise, other items that were clearly deliberately stored away from view were not part of the analysis.

Other aspects of material culture, such as the number of pig mandibles and water buffalo horns displayed on the exterior of the houses, were recorded instead, as these represented the animals slaughtered at past feasts hosted by the households. House maps also included information related to house size and layout of the interiors (Fig. 9).

Establishing a link between household material culture and tomb building was considered particularly important due to the spatial arrangement of tombs in relation to houses. According to traditional practice, megalithic tombs are built in the clan ancestral village. Within each ancestral village are the main ancestral uma houses of a clan. In Kodi, there are traditionally four ancestral houses in an ancestral village, along with several affiliated uma karekatena branch houses. The houses front the ceremonial center, which is surrounded by large stone tombs and is the venue in which large 


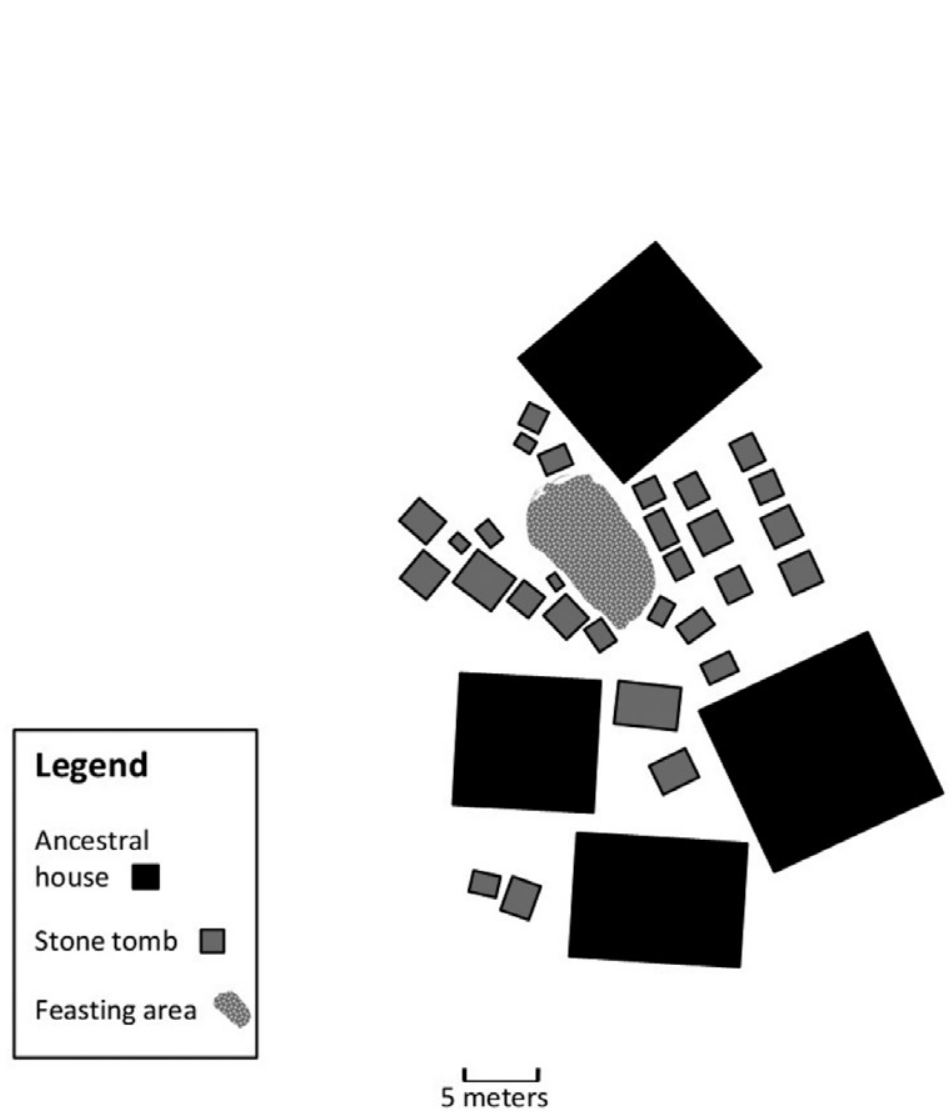

Fig. 10. Map showing configuration of ancestral houses and tombs in the Wainjolo Wawa clan ancestral village.

clan-wide feasts are held (Fig. 10). While many tombs are situated in front of ancestral houses, many others are located beside and behind houses due to lack of space within the center of the village. Furthermore, many tomb-building households reside outside of their affiliated ancestral village altogether. Some tombs are even situated adjacent to fields outside of the ancestral village where mock battles called pasola are conducted on horseback. It is therefore not necessarily possible to link tombs with tomb-building households in Kodi based on spatial orientation alone (a situation that applies to many archaeological contexts of monumentality).

\section{Food-Serving Items}

Commonly used items to serve and consume food at feasts include bowls, spoons, plates, and glasses (Fig. 11). Plates were typically made of glass or porcelain, although plastic plates were also used during feasts and for serving rice. Wooden plates were used traditionally in West Sumba and some were still kept by a few households. Bowls were most often made of plastic and used for serving meat at feasts, while rice was served 


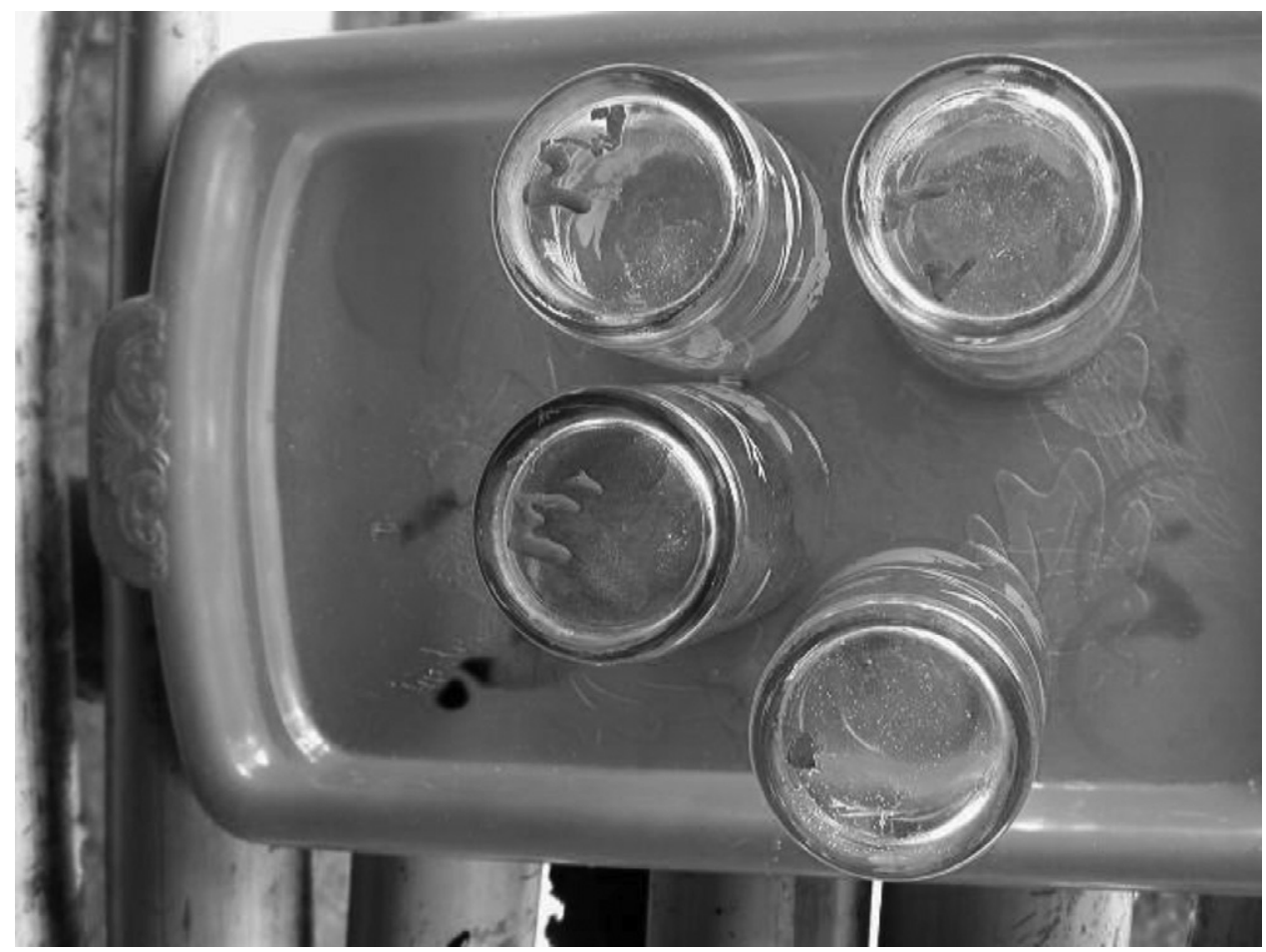

Fig. 11. Glass tumblers used for regular household meals and feasting in Kodi, West Sumba, 2005. (Photo by Ron Adams.)

separately on plates. Glass tumblers were used for serving coffee and tea at feasts. Spoons used for everyday meals and feasts were made of standard stainless steel.

In the analyses of this material culture, households owning the largest quantities of items related to food serving and food consumption were expected to be the most active in participating in feasting activities, including those associated with tomb building. Because roughly identical numbers of each of the various types of foodserving items were used at feasting events, an aggregate count was established for the combined number of bowls, plates, spoons, and glasses owned by each household. Not surprisingly, households that had previously sponsored the construction of a tomb tended to own more bowls, plates, glasses and spoons than households that had not built a tomb (Fig. 12). However, the ownership of household food serving items correlated very weakly with feasting investments overall (i.e., not limited to feasts held for tomb building) (Fig. 13). Moreover, there was a weak negative correlation between the ownership of food-serving items and household wealth, indicating that the presence of these items in a household is not a very useful material indicator of the overall pattern established in the above analyses linking wealth, tomb building, and feasting.

There are a number of factors that appear to account for the absence of a strong correlation between feasting and the ownership of food serving implements. One of the more obvious explanations is that these items are typically pooled together among a variety of households within a clan when a large feast is held. Because of this pooling, items such as drinking glasses often contain marks of ownership so that they can be 


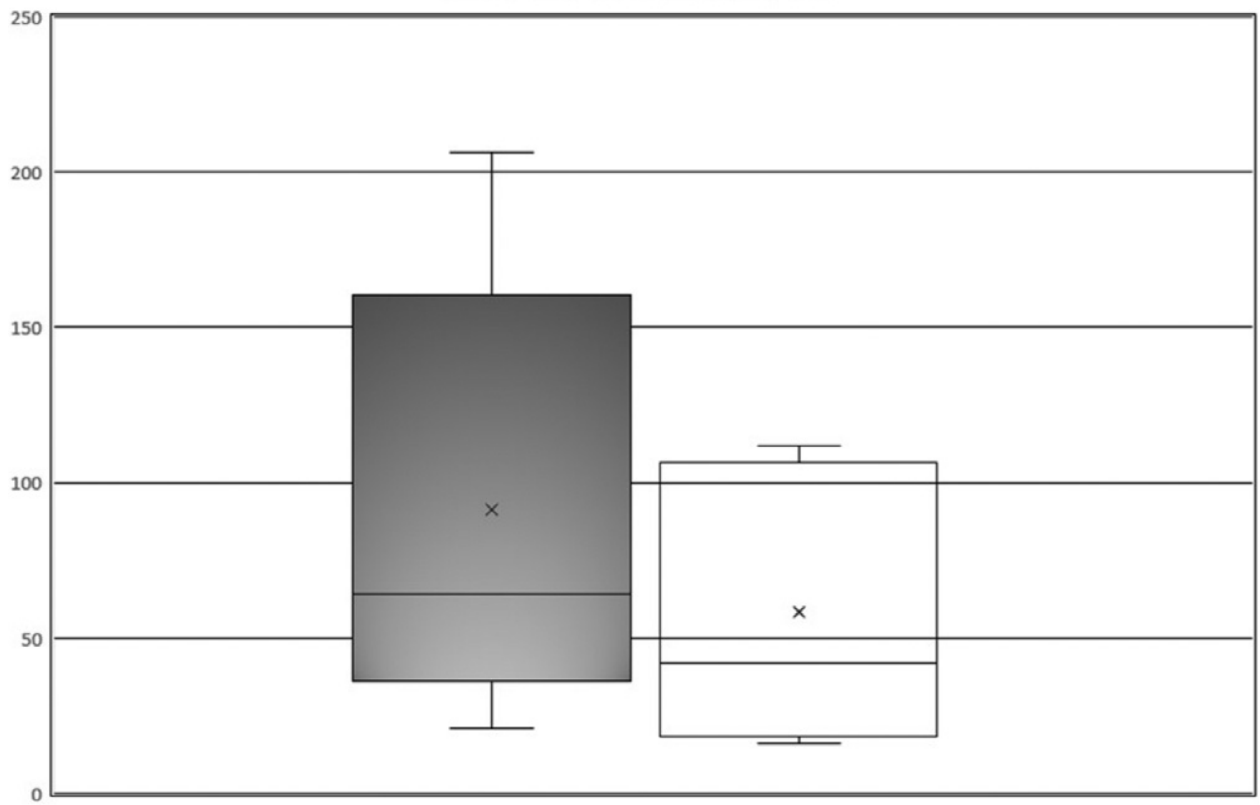

$\square$ Households that have built a tomb $\square$ Households that have not built a tomb

Fig. 12. Box plot of relationship between megalithic tomb building and household ownership of food serving items including plates, glasses, serving bowls, and spoons.

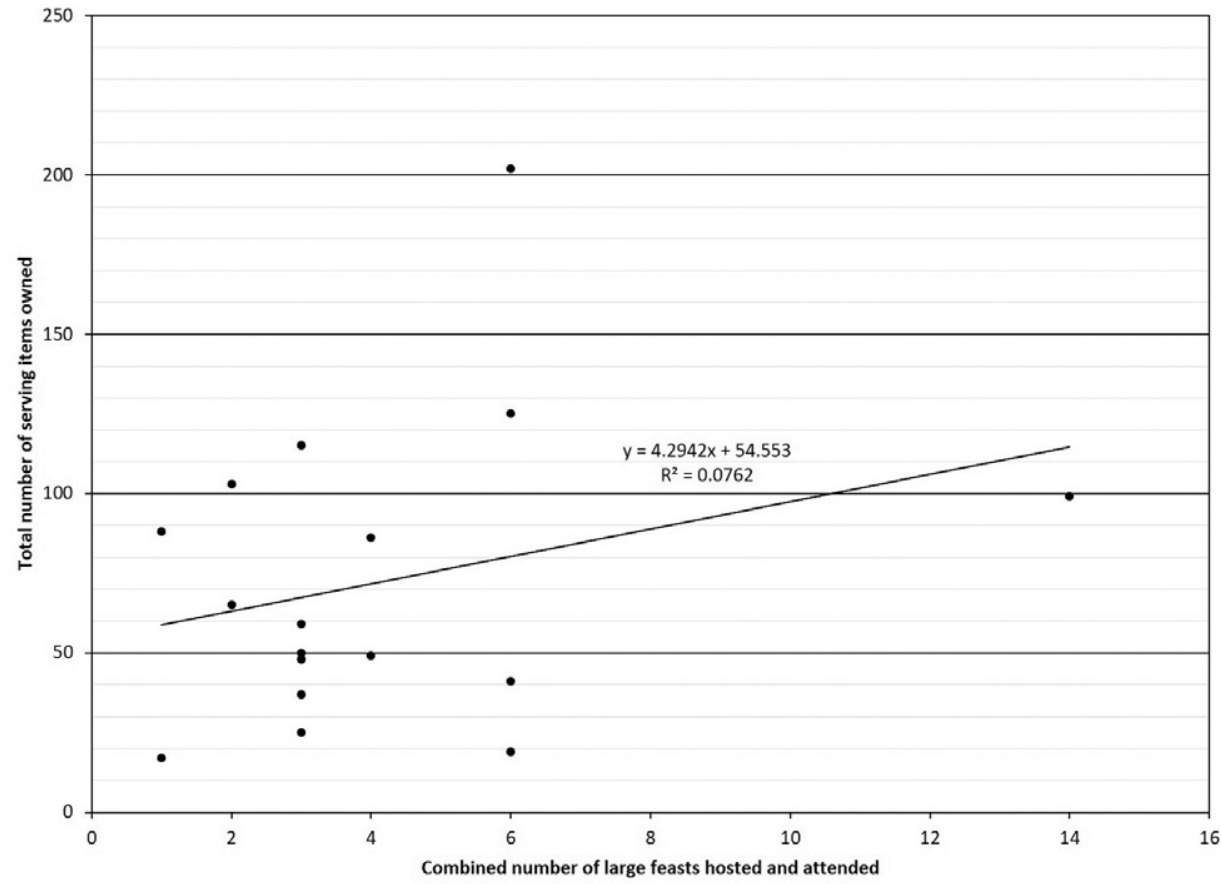

Fig. 13. Scatter plot illustrating relationship between combined number of feasts hosted and attended (with livestock contribution) in past ten years and household ownership of food serving items. 
retrieved by the owner at the conclusion of a large feast. The practice of pooling dishes for feasts among multiple households is also common in the Torajan highlands of Sulawesi, in which a similar study of feasting and material culture found generally weak correlations between ownership of food-serving items and feasting behavior (Adams 2001, 2004). The traditional emphasis on clan solidarity in the Kodi area may encourage the collective pooling of material culture for feasts in this regard. The relative infrequency of hosting large feasts among the interviewed households (no household reported hosting more than five large feasts in the ten-year period prior to the interviews) could also lessen the perceived need to accumulate large quantities of food-serving related items for feasts. Issues related to inaccurate reporting and items being stored away in another house or otherwise out of view could also contribute to these results.

Pots

Pots represent the primary item of cookery used among households in Kodi. Food is cooked in aluminum or sometimes ceramic pots for everyday meals and for large feasts. Raw numbers of pots in households were compared with tomb building, feasting, and wealth data. Because of the presence of multiple pot size grades, the cumulative diameter of all pots within a household was also used for the analysis, as was the ownership of large pots (those with estimated diameters of $20 \mathrm{~cm}$ or greater) that were typically reserved for preparing large amounts of food. As was the case for food-serving items, there were no meaningful correlations between the ownership of pots (number of pots owned, total cumulative diameter of pots owned, and number of large pots owned) and the categories associated with feasting, tomb building, and wealth. These results are likely attributable to the same issues related to borrowing and infrequent hosting of large feasts noted in the above analysis of food-serving items.

\section{Feasting Faunal Remains Display and House Size}

Displayed Feasting Faunal Remains - Displays of bucrania and pig mandibles are a relatively widespread practice cross-culturally. Displaying faunal remains (namely from slaughtered pigs and water buffaloes) from past feasts is a common practice among traditional societies in and around Southeast Asia, including western Papua New Guinea (Hampton 1999:147, 148), the Akha of northern Thailand (Clarke 1998:198; Hayden 2001:56; Hayden 2016:61), hill tribes of Vietnam (Hayden 2016:152, 168), the Torajan highlands of Sulawesi (Adams 2004), and various traditional societies in northeastern India (the Dafla, Adi, Chin, and Naga) (Simoons 1968). In prehistoric contexts, pig skulls considered to have been symbols of wealth and power have been found in burials of the Neolithic in China (Kim 1994). Livestock more generally, primarily cattle but also pigs, was used in symbolic imagery, and in ritual and mortuary contexts in the European Neolithic as well (Döhle and Stahlhofen 1985; Hodder 1990:250; Orton 2010; Russell 1998:50; Thomas 1991:23-25).

Water buffalo horns and pig mandibles displayed in the front section of houses in West Sumba represent animals slaughtered for past feasting events held at the house (Fig. 14). Water buffalo horns are displayed either on the exterior walls or, often more commonly due to theft concerns, on interior posts of houses, and pig mandibles are displayed on the underside of roof overhangs that cover the front verandas of houses or on the undersides of the roofs within the front rooms of houses (on the left side of the house looking out) (Fig. 15). 


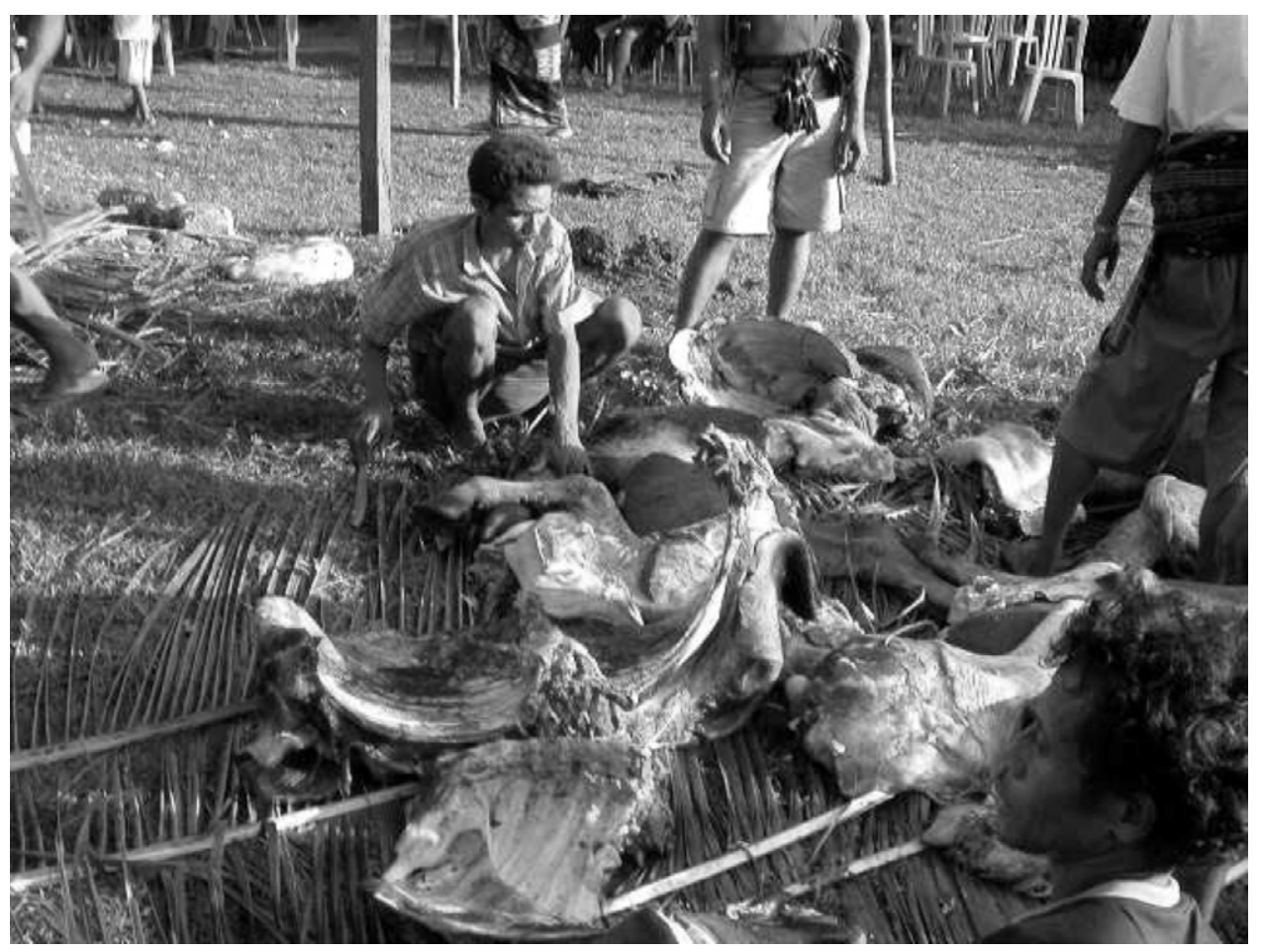

Fig. 14. Butchering water buffalo at a funeral feast in Pero village, West Sumba, 2005. (Photo by Ron Adams.)

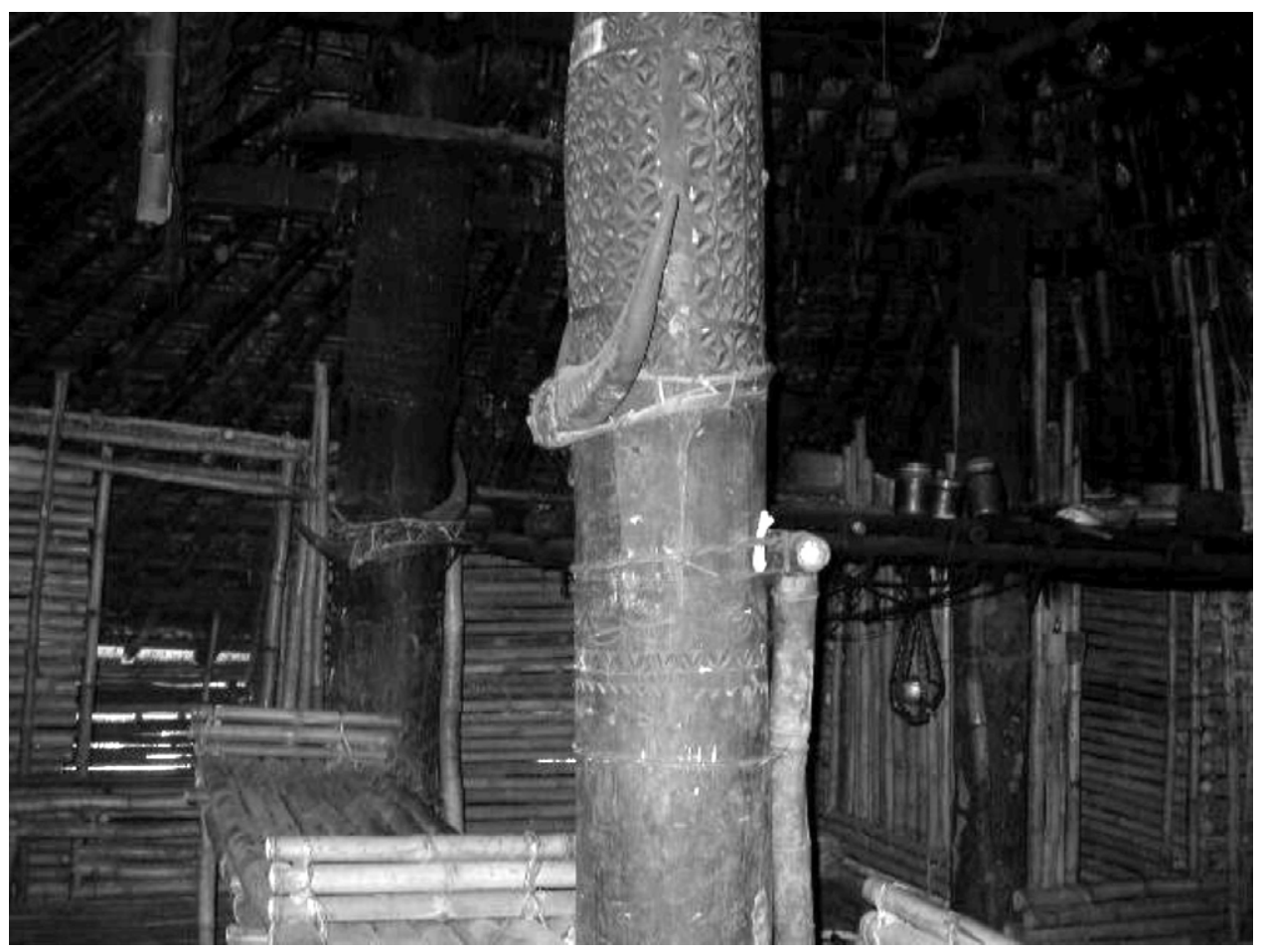

Fig. 15. Buffalo horns displayed in interior of an ancestral house in Wainyapu village, West Sumba, 2005. (Photo by Ron Adams.) 


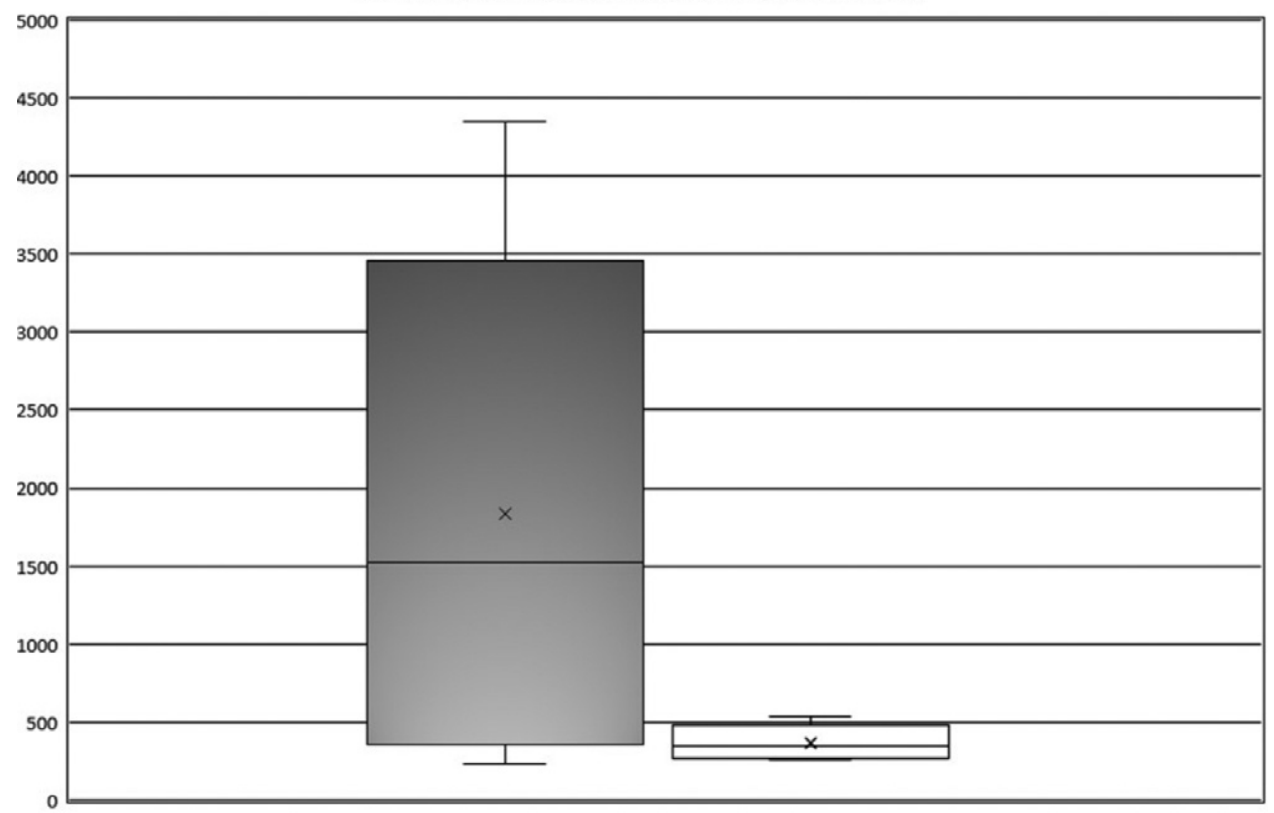

$\square$ Houses with water buffalo horns displayed $\square$ Houses without water buffalo horns displayed

Fig. 16. Box plot of relationship between household income and display of buffalo horns.

Among the West Sumba households analyzed, comparing the display of water buffalo horns and pig mandibles to indices of tomb building did not reveal any meaningful relationships. On the other hand, there was a clear association between household wealth and the display of water buffalo horns, at least when examining a presence vs. absence of displayed bucrania, although a similar pattern did not hold for the display of pig mandibles (Fig. 16). However, a T-test revealed that the connection between household wealth and the display of water buffalo horns was statistically insignificant.

There was also a positive correlation between the combined display of water buffaloes and pig mandibles and feasting, particularly the hosting of large feasts (Fig. 17). Contrary to expectations based on the data trend, a Yates continuity correction cross-tabulation $\chi^{2}$ test indicated that this connection between hosting large feasts and display of these faunal remains was also not statistically significant.

Unlike the other categories of material culture, the households used in analyzing water buffalo horn and pig mandible display were limited to those in which the household heads were considered to be the patriarchal heads of the uma ancestral house or uma karekatena branch ancestral house in which they resided, resulting in a particularly small sample size $(n=11)$, which likely accounts for the absence of statistically significant correlations between the display of these items and wealth, feasting, tomb building, and marriage expenses. Households excluded from this sample were caretakers residing in uma and uma karekatena who were not necessarily considered the house owners. In these instances, the pig mandibles and water buffalo horns displayed in the house reflected the feasting behavior of the owners, who were 
Number of water buffalo horns and pig mandibles displayed at house

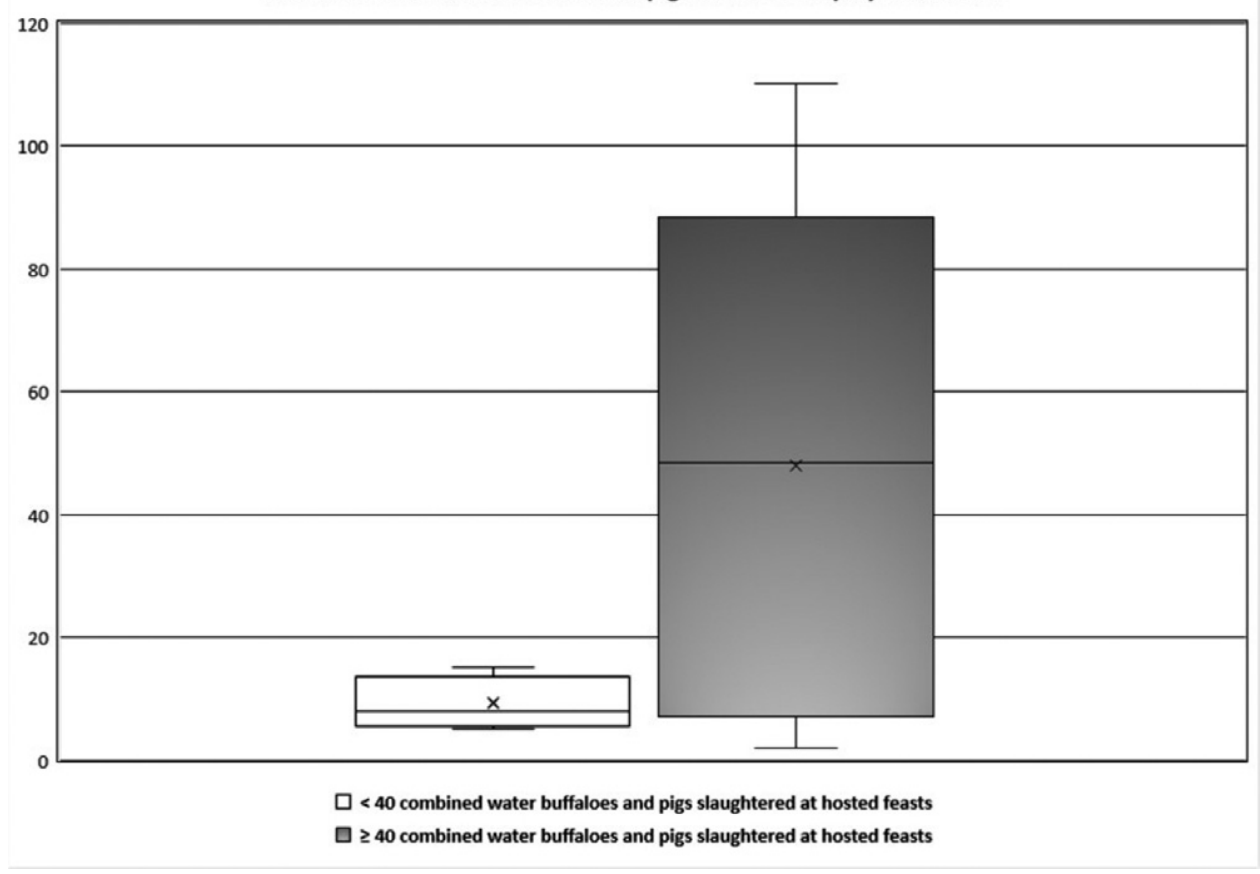

Fig. 17. Box plot of relationship between household display of pig mandibles or buffalo horns and hosting large feasting events.

living elsewhere, and not the caretakers. However, other material culture within the house, such as food-serving items, is typically owned by the caretaker households, and these households were thus not omitted from other material culture analyses.

Apart from the issue of the small sample size, the inconsistent results from the analyses of water buffalo horn and pig mandible display may be attributable to the longevity of ancestral houses. While uma ancestral houses are rebuilt periodically, the associated water buffalo horns and pig mandibles are often stored away when the houses are being rebuilt and redisplayed upon completion. As a result, many of the water buffalo horns and pig mandibles displayed on a house could represent feasting events of previous generations in some cases. Furthermore, due to theft concerns, water buffalo horns are not always displayed, even though the households may possess numerous sets of horns. Consequently, most households did not have more than two sets of water buffalo horns, while some had none displayed at all.

House Size - Given the visibility of ancient house sizes in the archaeological record, house size could be the most reliable material signature of a pattern linking tomb building, feasting, and wealth. Indeed, as noted previously, Kamp's (2000) ethnoarchaeological work found house architecture to be a more reliable indicator of household wealth than material objects.

Surveyed house sizes in this study ranged between 39 and $204 \mathrm{~m}^{2}$, with an overall mean of $128 \mathrm{~m}^{2}$. The smallest house in the sample, a common garden house, skewed this size range. All of the remaining houses were either uma ancestral houses or karekatena branch ancestral houses; these were all larger and architecturally more 
elaborate structures than simple garden houses, with interior carved posts and outstanding high-peaked roofs, an iconic element of the cultural landscape throughout the island of Sumba. When comparing the ancestral houses and branch ancestral houses only, the sizes ranged between 83 and $204 \mathrm{~m}^{2}$, with a mean house size of $133 \mathrm{~m}^{2}$ and a median house size of $127 \mathrm{~m}^{2}$.

As was the case with bucrania and pig mandible display, comparisons of house size in this study were complicated by the presence of many uma and uma karekatena houses that were more representative of the larger uma clan sub-group than any one particular household residing within the uma at a given time. The locations of uma houses are fixed over time, and, over the course of their lifespan, uma have undoubtedly been occupied by prominent tomb building households at different times. As a result, data analyses revealed no significant links between house size and feasting, tomb building, marriage expenditures, or wealth. The same lack of meaningful patterning was also found when comparing other aspects of house architecture, such as the numbers of rooms and seating benches, to these categories.

The display of water buffalo horns and pig mandibles from past feasts and house size proved to be problematic indices of individual household behavior. These results appear to primarily be a byproduct of the social structures linked to ancestral house architecture. Namely, the corporate nature of uma ancestral houses and their long-term histories make house architecture and fixed displays associated with houses unreliable reflections of the households residing in the structures at a given time.

\section{DISCUSSION}

The results of this analysis of household data demonstrate the potential utility and limitations of identifying household-scale behavioral patterning. According to tradition, megalithic tomb building, feasting, and the sponsorship of marriage-related payments are linked to sociopolitical power and wealth within clan groups in West Sumba. The data from household inventories in the Kodi area of West Sumba indicate that there were positive associations between feasting and household wealth as well as household wealth and marriage sponsoring. Tomb-building households also tended to be wealthier than non-tomb-building households and there was a positive correlation between tomb size and household wealth. These results strongly suggest that there are material advantages (and not just social prestige) tied to the achieved status attained by the degree to which one invests in large feasts, marriages, and megalithic tomb building.

The links between wealth, feasting, tomb building, and marriage are indicative of a scenario in which relation building is key to enhancing one's sociopolitical clout and thereby expanding one's access to wealth. Sponsoring tomb building, bride-price payments, and feasts all require the support of relations from both within and outside of one's clan. These undertakings also provide venues for households to enhance their standing within the clan and expand their network of supporters from other clans. Traditionally, the tangible benefits of these networks include support in times of dispute and access to clan labor. In the modern context, these benefits can include the acquisition of administrative posts, not unlike the global pattern of placing great importance on knowing the right people. Similar results were found among contemporary Maya villages, where one of the most reliable indicators of a household's wealth was the size of their social network (Hayden and Cannon 1984:176). 
However, the household data from Kodi also indicate that identifying this household-scale behavioral patterning in material culture and house architecture is problematic. The relationship between household material culture and feasting or tomb building was found to be weak. The ownership of items related to food consumption, preparation, and serving at feasts (including tomb building feasts) did not correlate well with household feasting and tomb building. None of the comparisons between feasting material culture and reported levels of household wealth and feasting investments revealed the expected types of correlations. While there were positive correlations between material culture and feasting/tomb building in some cases (such as with cooking pots), the relationships were weak.

This lack of correspondence between objects of feasting-related material culture owned by individual households and household investments in tomb building and feasting does appear to reflect the importance of social groups as frameworks for social action. It was acknowledged among informants that a great deal of loaning and borrowing within the clan of plates, glasses, pots, and other items occurred when a large feast was held. In an analysis of feasting-related material culture and feasting behavior in Tana Toraja, a similar lack of correspondence between the ownership of feasting-related material culture and household feasting investments was found (Adams 2004). In the case of Tana Toraja, the study was conducted in an area where interhousehold solidarity was emphasized in many of the traditional practices, including feasts. In the Kodi area of West Sumba, while individual household achievement was strongly associated with the sponsorship of tomb construction, marriage, and large feasts, there was a strong ethic of solidarity within the clan. Indeed, the large feasts and tombs are considered not only to enhance the prestige of the individuals who sponsored the endeavors but also the clans as a whole.

Accordingly, given this scenario of household intra-clan solidarity, a collective provisioning of livestock for feasts often occurred among fellow clan members. In spite of the fact that the individual households of the events' primary sponsors attained the most renown as a consequence of acting as the host of a large feast and sponsoring megalithic tomb building, it is not uncommon for the total livestock contributions contributed by fellow clan members for a feast to nearly equal and sometimes exceed those contributed by the primary sponsor. This is most common for feasts held for the construction of uma ancestral houses, in which more than half of the total livestock contributions are from non-sponsoring households within the clan. In the case of the most lavish feasts (i.e., woleka, thanksgiving feasts) held in Kodi, the collective livestock contributions from fellow clan members can even exceed those of the primary sponsor. For tomb building, there can be a collective provisioning of livestock for the various feasts held as well, although the primary sponsor typically provides more than half of the livestock in these cases (Adams 2007b:350). The collective provisioning of feastingrelated material culture seems to be indicative of the same intra-clan solidarity ethic.

In terms of the household display of faunal remains from past feasts, analyses results are a little more complex. Certainly, the correlation between the display of water buffalo horns and pig mandibles with feasting (especially hosted feasts) is strong and consistent with the fact that these remains represent animals slaughtered at the feasts hosted by the household that display these items. Similarly, the correlation between the display of water buffalo horns and household wealth coincides with the use of water buffalo horns as one of the primary symbols of traditional wealth and renown. However, water buffalo horns and pig mandibles from animals slaughtered at past feasts 
hosted by a household can be displayed on uma ancestral houses and uma karekatena branch houses over successive generations, even after the house has been rebuilt. Thus the display of these remains does not necessarily reflect the behavior of the current inhabitants of a house. Indeed, in the context of achieved status and lack of transgenerational authority in Kodi, fortunes can change from generation to generation.

Perhaps more than other factors, the dominance of uma ancestral houses and uma karekatena branch houses in the sample complicated the attempts to decipher material culture patterning at the individual household level, as large feasts are traditionally hosted at the uma regardless of whether the primary sponsor of the feast resides in the ancestral house. For example, the display of water buffalo horns and pig mandibles may be more appropriately viewed as reflecting the larger group associated with the house as a collective as opposed to the individual household occupying the ancestral house at a given time. A study involving a larger sample size of ancestral houses and clans would be necessary to gauge how the display of these feasting remains and aspects of household architecture relate to the past feasting sponsored by various households of the uma.

In any case, more ephemeral remnants of feasting are most likely to be found in the vicinity of the uma in the ceremonial center of the clan ancestral village. This evidence would consist of ashy lenses at the locations of temporary kitchens built adjacent to the uma ancestral house (behind, in front, or to the side of the house) of the feast host. The bones of water buffaloes and pigs slaughtered also constitute reliable evidence of past feast, although they are not found in neatly consolidated deposits. These bones are instead displaced by dogs or removed to other villages when meat is distributed to guests to take home at the end of certain feasts, resulting in a dispersion of bones in numerous villages after a single large feast (Jeunesse and Denaire 2017). Nevertheless, it is not uncommon to see bones scattered haphazardly on the ground within the ceremonial center of the clan ancestral villages.

\section{Archaeological Implications}

The results of this study should be most relevant to the archaeological investigations of societies in the Indonesian archipelago where megalith building or lavish feasting occurred in the past. In West Sumba and elsewhere in Indonesia, this pattern likely emerged sometime during the early part of the second millennium A.D., as has been demonstrated by Bonatz, Neidel, and Tjao-Bonatz (2006) on Sumatra and is reflective of current evidence elsewhere in the archipelago (Steimer-Herbet 2018; SteimerHerbet and Besse 2016).

It is not possible to ascertain the precise degree to which modern influences have affected the household-level material culture distributions analyzed in this study, apart from the presence of items of material culture such as aluminum pots, glass tumblers, and plastic bowls that were not used at feasts in the ancient past. At the same time, ancient practices of feasting and tomb building remain active and relevant and still involve many traditional methods (e.g., slaughtering techniques and stone-dragging methods) and traditional spatial contexts within ancestral villages. Because of the overall lack of strong relationships between household material culture and tomb building or feasting, any archaeological model derived from the Kodi data should be more concerned with material culture patterns that transcend the level of individual households to include broader patterns within villages where the remains of feasting 
and tomb building activities would likely be concentrated. Such a model for the identification of societies in which megalith building and feasting played a similar role to that in Kodi should therefore include:

(1) Evidence for wealth variability, possibly limited to the presence of exotic items (e.g., gold ornaments, imported ceramics), differential megalith sizes, and differential concentrations of certain displayed faunal remains;

(2) Evidence for social structures oriented around corporate groups, such as tombs with several interments and house size grades reflecting the difference between the more elaborate architecture associated with large lineage-type houses and smaller private houses;

(3) The remains of large domesticated animals slaughtered for feasts, including those held in the process of megalith building since the slaughter of livestock in West Sumba and numerous other societies in Southeast Asia is limited to these types of occasions (Hayden 2016);

(4) The remains of large pots suitable for food preparation at feasting occasions, although variability in the amount of these finds between different house locations should not be expected to be great; and

(5) Evidence for temporary kitchens outside of houses suitable for preparing large quantities of food for feasts.

Ethnographies of megalith-building societies elsewhere in Indonesia describe social phenomena similar to that in Kodi. In areas of Sulawesi, Flores, Sumatra, and Nias, where megalith-building remains a living tradition or has only ceased in recent historic times, societies traditionally have been organized at a mid-level and centered around corporate descent groups in which feasting appears to have played a prominent role (Adams 2001, 2007b; Barbier 1988; Beatty 1992; Feldman 1988; Forth 2001; NooyPalm 1979; Sherman 1990). Thus, it is reasonable to postulate that material culture patterning among households and villages in many contexts of the Indonesian megalithic phenomenon would be comparable to the Kodi model outlined here.

In terms of the archaeological relevance of this study beyond Indonesia and Southeast Asia, ethnoarchaeological and ethnological studies of living megalithic societies have long been used by archaeologists to interpret megalithic phenomena far removed in time and space from living ethnographic examples. In particular, the megalithic tradition in Madagascar has been recognized by many archaeologists as an appropriate analog for the interpretation of megaliths of the European Neolithic ever since anthropologist Maurice Bloch provided descriptive accounts of the living tradition associated with megalithic dolmen tombs (similar in form to those from the European Neolithic) among the Imerina in the central plateau of Madagascar (Bloch 1971, 1981). Bloch's (1971) description of the collective interment within these tombs of members of corporate descent groups was of particular interest to some archaeologists and became an important aspect of Chapman's (1981) model linking megaliths of Neolithic Europe to corporate groups.

Among notable early ethnoarchaeological works dealing with megaliths in Madagascar, Joussaume and Raharijaona (1985) documented standing menhir stones and dolmen tombs and explored the origins of the collective burial tradition among the Imerina. Parker Pearson (1992) significantly added to the discussion of megaliths in Madagascar and their relevance to the archaeology of the European Neolithic by exploring the historic context of the megalithic tradition in the Androy area of Madagascar and providing detailed accounts of the effort required to build tombs and hold elaborate funeral feasts. In later work, Parker Pearson and Ramilisonina (1998) highlighted the symbolic dichotomy between stone and wood in Androy and their 
respective associations with death (stone) and life (wood). These symbolic associations formed the basis of an interpretation of Stonehenge as a place for the ancestors and rituals for the dead, while large timber constructions such as Woodhenge and Durrington Walls) were domains of the living and the places where rituals associated with the living were held (Parker Pearson and Ramilisonina 1998). Similarly, Kus and Raharijaona (1998) provided detailed descriptions of megalith quarrying and building in the Imerina area of Madagascar and emphasized the historical connection between megaliths and ruling sovereigns, which reinforced the symbolic notion of the sovereign acting as an intermediary between the earth and sky.

Other, more recent ethnoarchaeological investigations on Sumba and Tana Toraja on the Indonesian island of Sulawesi have been concerned specifically with archaeologically operational data sets to address questions relating to phenomena evident in the archaeological record of the European Neolithic. Jeunesse and Denaire (2017, 2018) have examined the deposition of livestock bones following feasting events in these areas, as well as patterns of collective burial practices. These approaches have expanded the potential insights gained from ethnoarchaeological studies of traditional megalith-building societies that have traditionally emphasized broader social and symbolic approaches.

The study of households in Kodi can perhaps most effectively contribute to interpretations of ancient megalith-building societies globally by revealing data patterns that appear to coincide with the context of collective social action in Kodi. Archaeological studies of megaliths-building societies in Europe and Asia have emphasized the likely presence of group-oriented social structures associated with these monuments (Chapman 1981, 1995; Hinz 2007; Kim 2014; Lidén 1995; Madsen 1982; Renfrew 1976; Sjögren 1986), a notion bolstered by the many ethnographic examples of megalithic traditions occurring in corporate group social structures (Adams 2001; Beatty 1992; Bloch 1971; Feldman 1988; Forth 2001; Jacobs 1990; Sherman 1990; Simoons 1968). More specifically, archaeological remains from Neolithic-aged houses in Britain and Ireland point to the existence of group-oriented house societies in those areas (Smyth 2010; Thomas 2016). In northern Germany and southern Scandinavia, evidence indicates the existence of small households that appear to express collective identities through megalith building during the late fifth and early fourth millennium B.C. (Furholt and Müller 2011). Likewise, longhouse occupations during the time of megalithic dolmen building during the early Mumun (1300-700 B.C.) on the Korean peninsula appear to have existed in a context during which the expression collective identity was enhanced in ritual activities (Kim 2014). Importantly, the wealth variability among Kodi households demonstrates that the material characteristics suggesting the presence of group-oriented social structures in these archaeological examples do not also necessarily indicate the existence of egalitarian societies.

\section{CONCLUSIONS}

Ethnoarchaeological examination of household investments in important realms of social action and household material culture patterning has the potential to offer valuable insights into past societies. The survey of households presented in this case study of a megalith-building society in West Sumba illustrates the potential for better understanding the inner-workings of past megalith-building societies in appropriate contexts for comparison. While household material culture related to past megalithic 
tomb building and feasting was present among households in this survey, household variability in the ownership of these items could generally not be linked in a strong way to past levels of investments in feasting and building tombs. Among the many factors affecting this lack of patterning, the most significant and convincing appears to be the presence of group structures centered around clan (parona) and smaller lineage (uma) frameworks in which a tradition of solidarity and collective prestige was and continues to be important. Even in the case of tomb building and feasting, undertakings that are highly linked to the achievement of personal renown and sociopolitical power, collective prestige accrues to the larger group. The balancing of individual aggrandizement and concerns for solidarity appears to be reflected in the household architecture associated with these groups and in the material culture patterning within households. A more expansive study comparing the variability among clans and lineages as a whole would be appropriate for further exploring the relationship between these undertakings and the collective material culture patterning of these groups.

\section{ACKNOWLEDGMENTS}

The ethnoarchaeological data for this study were collected as a part of fieldwork conducted for my Ph.D. thesis at Simon Fraser University, for which Brian Hayden acted as the senior supervisor. Brian's ongoing support for this and related endeavors has been greatly appreciated. The work, of course, would not have been possible without local collaborators on Sumba, including Piter Rehi, Thomas Tedawonda, Agusthinus Galugu, Pak Agustinus Sabarua, Pak Rehi Pyati, Pak Octavianus Ndari, Umbu Siwa Djurumana, and many informants, whose patience and willingness to share their cultural traditions will always be appreciated. Others who contributed to the successful completion of this work include Suzanne Villeneuve, Webb Keane, and Janet Hoskins. The project was funded by the Social Sciences and Humanities Research Council of Canada and was conducted in collaboration with Haris Sukendar (Pusat Penelitian Arkeologi Nasional, Jakarta) and Ayu Kusumawati (Balai Arkeologi Denpasar). Field research in Indonesia was undertaken with permission from the Indonesian Academy of Sciences (LIPI). Lastly, I would like to thank two anonymous reviewers for their insightful comments on a previous version of this article, as well as the invaluable editorial guidance provided by Mike Carson and Rowan Flad. Any remaining shortcomings in this article are the sole responsibility of the author.

\section{REFERENCES CITED}

ADAMS, Ron L.

2001 Ethnoarchaeology of Torajan Feasts. M.A. thesis. Simon Fraser University, Burnaby, British Columbia.

2004 An ethnoarchaeological study of feasting in Sulawesi, Indonesia. Journal of Anthropological Archaeology 26(1):56-78.

$2007 a$ The Megalithic Tradition of West Sumba, Indonesia: An Ethnoarchaeological Investigation of Megalith Construction. Ph.D. thesis. Simon Fraser University, Burnaby, British Columbia.

$2007 b$ Maintaining cohesion in house societies of West Sumba, Indonesia, in The Durable House: House Society Models in Archaeology: 344-362, ed. Robin A. Beck, Jr. Occasional Paper 35. Carbondale: Center for Archaeological Investigations, Southern Illinois University.

2010 Megaliths, power, and social relations in West Sumba, Indonesia, in Monumental Questions: Prehistoric Megaliths, Mounds, and Enclosures: 279-284, ed. David Calado, Maxiliam Baldia, and Matthew Boulanger. Proceedings of the 15th World Congress of the International Union for Prehistoric and Protohistoric Sciences (Lisbon, 4-9 September 2006), BAR International Series 2123. Oxford: British Archaeological Reports. 
ARndt, PAUL

1932 Die Megalithenkultur der Nad'a (Flores) [The Megalithic Culture of Nad'a (Flores)]. Anthropos 27:11-63.

ARTHUR, JohN W.

2009 Understanding household population through ceramic assemblage formation: Ceramic ethnoarchaeology among the Gamo of Southwestern Ethiopia. American Antiquity 74(1):31-48.

Ashmore, Wendy, and Richard R. WiLK

1988 Household and community in the Mesoamerican past, in Household and Community in the Mesoamerican Past: 1-27, ed. Richard R. Wilk and Wendy Ashmore. Albuquerque: University of New Mexico Press.

Barbier, JeAn PaUl

1988 A stone rider of the Batak of Sumatra, in Islands and Ancestors: Indigenous Styles of Southeast Asia: 50-65, ed. Jean Paul Barbier and Douglas Newton. New York: Te Neues Publishing.

BEATTY, ANDREW

1992 Society and Exchange in Nias. Oxford: Clarendon Press.

BellwoOd, Peter

2007 Prehistory of the Indo-Malaysian Archipelago. Canberra: Australian National University E Press.

Bloch, Maurice

1971 Placing the Dead: Tombs, Ancestral Villages, and Kinship Organization in Madagascar. London: Seminar Press.

1981 Tombs and states, in Mortality and Immortality: The Anthropology and Archaeology of Death: 137-147, ed. S. C. Humphreys and Helen King. New York: Academic Press.

Bonatz, Dominik, John David Neidel, and Mai Lin TJao-Bonatz

2006 The megalithic complex of highland Jambi: An archaeological perspective. Bijdragen tot de Taal-, Land-en Volkenkunde 162(4):490-522.

Bowser, Brenda J., and John Q. Patton

2004 Domestic spaces as public places: An ethnoarchaeological case study of houses, gender, and politics in the Ecuadorian Amazon. Journal of Archaeological Method and Theory 11(2): 157-181.

Brumfiel, Elizabeth, and Cynthia Robin

2008 Gender, households, and society: An introduction, in Gender, Households, and Society: Unraveling the Threads of the Past and the Present: 1-16, ed. Cythnia Robin and Elizabeth Brumfiel. Archaeological Papers of the American Anthropological Association 18(1). Arlington, VA: American Anthropological Association.

BüHLER, AlFred

1951 Bemerkungn zur Kulturgeschichte Sumbas [Remarks on the culture history of Sumba], in Südseestudien, Gedenkschrift zur Erinnerung [South Sea Studies: A Commemorative Volume]: 51-76, ed. Felix Speiser. Basel: Museum für Völkerkunde.

BYRD, BRIAN F.

2000 Households in transition: Neolithic social organization within southwest Asia, in Life in Neolithic Farming Communities: Social Organization, Identity, and Differentiation: 63-98, ed. Ian Kuijt. New York: Kluwer Academic/Plenum Press.

Chapman, Robert

1981 The emergence of formal disposal areas and the 'problem' of megalithic tombs in prehistoric Europe, in The Archaeology of Death: 71-81, ed. Ian Kinnes and Klavs Randsborg. Cambridge: Cambridge University Press.

1995 Ten years after: Megaliths, mortuary practices, and the territorial model, in Regional Approaches to Mortuary Analysis: 29-51, ed. Lane Anderson Beck. New York: Plenum Press.

Clarke, Michael J.

1998 Feasting Among the Akha of Northern Thailand: An Ethnoarchaeological Case Study. M.A. thesis. Simon Fraser University, Burnaby, British Columbia.

2001 Akha feasting: An ethnoarchaeological perspective, in Feasts: Archaeological and Ethnographic Perspectives on Food, Politics, and Power: 144-167, ed. Michael Dietler and Brian Hayden. Washington: Smithsonian Institution Press. 
Crystal, ERIC

1974 Man and the menhir: Contemporary megalithic practice of the Sa'dan Toraja of Sulawesi, Indonesia, in Ethnoarchaeology: 117-128, ed. Christopher B. Donnan and C. William Clewlow, Jr. Los Angeles: Institute of Archaeology, University of California, Los Angeles.

Djakababa, Cornelius Malo

2002 Raja Yoseph Malo of Sumba. Jakarta: ABADI Printing.

Döhle, Hans-Jürgen, and Heribert Stahlhofen

1985 Die neolithischen Rindergräber auf dem "Löwenberg" bei Derenburg, Kreis Wernigerode [The Neolithic cattle graves on the "Löwenberg" near Derenburg, Wernigerode]. Jahresschrift für mitteldeutsche Vorgeschichte 68:157-177.

Feldman, Jerome

1988 The seat of the ancestors in the homeland of the Nias people, in Islands and Ancestors: Indigenous Styles of Southeast Asia: 34-49, ed. Jean Paul Barbier and Douglas Newton. New York: Te Neues Publishing Company.

Flannery, Kent, and Marcus C. Winter

1976 Analyzing household activities, in The Early Mesoamerican Village: 34-44, ed. Kent Flannery. New York: Academic Press.

Forth, Gregory L.

2001 Dualism and Hierarchy: Process of Binary-Combination in Keo Society. Oxford: Oxford University Press.

Foster, Catherine P., and Bradley J. Parker

2012 Introduction: Household archaeology in the Near East and beyond, in New Perspectives on Household Archaeology: 1-12, ed. Bradley J. Parker and Catherine P. Foster. Winona Lake, IN: Eisenbrauns.

Furholt, Martin, and Johannes Müller

2011 The earliest monuments in Europe: Architecture and social structures (5000-3000 cal BC), in Megaliths and Identities: 15-32, ed. Martin Furholt, Friedrich Lüth, and Johannes Müller. Bonn: Dr. Rudolf Habelt.

Gillespie, S. D.

2000 Beyond kinship: An introduction, in Beyond Kinship: Social and Material Reproduction in House Societies: 1-22, ed. Rosemary A. Joyce and Susan D. Gillespie. Philadelphia: University of Pennsylvania Press.

Groeneveld, F. J.

1931 Memorie van overgave van den gezaghebber van West-Soemba, loopende over het tijdperk van 23 November to 2 Oktober 1931 [Memorandum of the surrender of the governor of West Sumba, spanning the period from 23 November to 2 October 1931]. Zug, Switzerland: Inter Documentation Company.

Hampton, O. W. "Bud"

1999 Culture of Stone: Sacred and Profane Uses of Stone among the Dani. College Station: Texas A\&M University Press.

HANDini, RETNO

2018 Jejak Nenek Moyang Orang Sumba [Evidence of the Ancestors of Sumbanese People] (online news article posted 15 January 2018), Max 96.9FM Waingapu (website). URL: https://www. maxfmwaingapu.com/2018/01/situs-lambanapu-jejak-nenek-moyang-orang-sumba/.

HAYDEN, BRIAN

2001 Fabulous feasts: A prolegomenon to the importance of feasting, in Feasts: Archaeological and Ethnographic Perspectives on Food, Politics, and Power: 23-64, ed. Michael Dietler and Brian Hayden. Washington: Smithsonian Institution Press.

2016 Feasting in Southeast Asia. Honolulu: University of Hawai'i Press.

Hayden, Brian, and Aubrey Cannon

1984 The Structure of Material Systems: Ethnoarchaeology in the Maya Highlands. SAA Papers 3. Washington, D.C.: Society for American Archaeology.

HinZ, MARTIN

2007 Territoriale und soziale Strukturen: Modelle zur Kollektivgrabsitte der Wartberg-Gruppe [Territorial and social structures: Models for collective burial custom of the WartbergGruppe]. Journal of Neolithic Archaeology 9:1-18. 
HODDER, IAN

1990 The Domestication of Europe: Structure and Contingency in Neolithic Societies. Oxford: Basil Blackwell.

Hodder, IAn, and Craig Cessford

2004 Daily practice and social memory at Çatalhöyük. American Antiquity 69(1):17-40.

HOSKINS, JANET

1984 Spirit Worship and Feasting in Kodi, West Sumba: Paths to Riches and Renown. Ph.D. diss. Harvard University.

1989 On losing and getting a head: Warfare, exchange, and alliance in a changing Sumba, 1888-1988. American Ethnologist 14(4):605-622.

JaCOBS, JULIAN

1990 The Nagas. New York: Thames and Hudson.

JANOwsKi, M.

2003 The Forest Source of Life. Occasional Paper 143 (and) Special Publication of the Sarawak Museum Journal. London: The Trustees of the British Museum (and) Kuching: The Sarawak Museum.

Jeunesse, Christian, And Anthony Denaire

2017 Origine des animaux sur pied, circuit de la viande: La formation des assemblages osseux dans le contexte d'une fête traditionnelle à Sumba (Indonésie), Une enquête ethnoarchéologique [The source of live animals, circulation of meat: The formation of faunal assemblages and the context of traditional feasts in Sumba (Indonesia), An ethnoarchaeological investigation]. Bulletin de la Société Préhistorique Française 114(1):115-136.

2018 Current collective graves in the Austronesian world: A few remarks about Sumba and Sulawesi (Indonesia), in Gathered in Death: Archaeological and Ethnological Perspectives on Collective Burial and Social Organization: 85-105, ed. Aurore Schmitt, Sylviane Déderix, and Isabelle Crevecoeur. Louvain, Belgium: Presses Universitaires de Louvain.

Jones, Samantha E., Huw James Barton, Chris O. Hunt, Monica Janowski, Lindsay Lloyd-Smith, AND GRAEME BARKER

2016 The cultural antiquity of rainforests: Human-plant associations during the mid-late Holocene in the interior highlands of Sarawak, Malaysian Borneo. Quaternary International 416:80-94.

Joussaume, Roger, ANd Victor RaharijaOna

1985 Sépultures mégalithiques à Madagascar [Megalithic burials in Madagascar]. Bulletin de la Société préhistorique française 82:534-551.

KAMP, KATHRYN

2000 From village to tell: Household ethnoarchaeology in Syria. Near Eastern Archaeology 63 (2):84-93.

Kapita, Oemboe Hina

1976 Sumba di dalam jangkauan jaman [Sumba in the deep scope of time]. Jakarta: BPK Gunung Mulia.

KeERs, W. C.

1938 Indrukken van het megalithische tijdperk van West-Soemba [Impressions of the Megalithic Era of West Sumba]. Tijdschrift van het Koninklijk Nederlandsch Aardrijkskundig Genootschap, 2e ser., 55:926-931.

KIM, JANGSUK

2014 From labor control to surplus appropriation: Landscape changes in the Neolithization of Southwestern Korea. Journal of World Prehistory 27:263-275.

Kim, SeUng-OG

1994 Burials, pigs, and political change in Neolithic China. Current Anthropology 35:119-141.

Koike, Макото

1986 Social organization in Eastern Indonesia: A historical perspective. Sha: A Record of Social Anthropology 46:1-22.

Kramer, CAROL

1979 An archaeological view of a contemporary Kurdish village: Domestic architecture, household size, and wealth, in Ethnoarchaeology. Implications of Ethnography for Archaeology: 139-163, ed. Carol Kramer. New York: Columbia University Press. 
Kuipers, Joel

1990 Power in Performance: The Creation of Textual Authority in Weyewa Ritual Speech. Philadelphia: University of Pennsylvania Press.

Kus, Susan, and Victor Raharijaona

1998 Between earth and sky there are only a few large boulders: Sovereignty and monumentality in central Madagascar. Journal of Anthropological Archaeology 17:53-79.

2000 House to palace, village to state: Scaling up architecture and ideology. American Anthropologist 102(1):98-113.

Kusumawati, Ayu

1997 Arah hadap kubur batu Sumba (Tinjauan melalui konsepsi Megalitik [Directional Orientation of Stone Tombs in Sumba (Observation through the Megalithic concept)]. Forum Arkeologi 1996-1997(2):1-11.

1998 Survei megalitik Sumba Barat, Nusa Tenggara Timur [Megalithic survey of West Sumba, East Nusa Tenggara]. Berita Penelitian Arkeologi 1998-1999(2):1-20.

2000 Faktor pertimbangan pemindahan pemukiman masyarakat megalitik di Nusa Tenggara Timur [Factors in the consideration of settlement movement within megalithic societies in East Nusa Tenggara]. Forum Arkeologi 1:8-20.

2002 Megalitik Dalam Pola Perkembangan Masyarakat Ende (Flores) Nusa Tenggara Timur [Megalithism within the patterns of community development in Ende (Flores) East Nusa Tenggara]. Berita Penelitian Arkeologi 2002:34-52.

LÉvi-Strauss, Claude

1983 The Way of the Masks. London: Jonathan Cape.

LIDÉN, KERSTIN

1995 Megaliths, agriculture, and social complexity: A diet study of two Swedish megalith populations. Journal of Anthropological Archaeology 14:404-417.

LyONS, DiAne E.

2007 Building power in rural hinterlands: An ethnoarchaeological study of vernacular architecture in Tigray, Ethiopia. Journal of Archaeological Method and Theory 14(2):179-207.

MADSEN, TORSTEN

1982 Settlement systems of early agricultural societies of east Jutland, Denmark: A regional study of change. Journal of Anthropological Archaeology 1:197-236.

Müller, Johannes, Robert Hofmann, and René Ohlrau

2016 From domestic households to mega-structures: Proto-urbanism?, in Trypillia Mega-Sites and European Prehistory 4100-3400 BCE: 253-268, ed. Johannes Müller, Knut Rassmann, and Mykhailo Videiko. Themes in Contemporary Archaeology 2. London: Routledge.

NEEDHAM, RODNEY

1960 Jātaka, Pañcatantra, and Kodi Fables. Bijdragen tot de Taal-, Landen Volkenkunde 116:232-262.

1983 Sumba and the Slave Trade. Working Paper 31. Melbourne: Department of Anthropology, Monash University.

NeLSON, Ben

1981 Ethnoarchaeology and paleodemography: A test of Turner and Lofgren's hypothesis. Journal of Anthropological Research 37(2):107-129.

Nooy-Palm, Hetty

1979 The Sa'dan-Toraja: A Study of Their Social Life and Religion, vol. 1. The Hague: Martinus Nijhoff.

Orton, David

2010 Both subject and object: Herding, inalienability and sentient property in prehistory. World Archaeology 42(2):188-200.

Parker Pearson, Mike

1992 Tombs and monumentality in southern Madagascar: Preliminary results of the central Androy survey. Antiquity 66:941-948.

Parker Pearson, Mike, and Ramilisonina

1998 Stonehenge for the ancestors: The stones pass on the message. Antiquity 72:308-332. 
Prasetyo, Bagyo

2013 Persebaran Dan Bentuk-Bentuk Megalitik Indonesia: Sebuah Pendekatan Kawasan [The extent and forms of Indonesian megaliths: A regional approach]. KALPATARU, Majalah Arkeologi 22(2):61-122.

Renfrew, Colin

1976 Megaliths, territories and populations, in Acculturation and Continuity in Atlantic Europe: 198-220, ed. Sigfried J. De Laet. Bruges: De Tempel.

RuSSELL, NARisSA

1998 Cattle as wealth in Neolithic Europe: Where's the beef?, in The Archaeology of Value: Essays on Prestige and the Processes of Valuation: 42-54, ed. Douglas W. Bailey. BAR International Series 730. Oxford: British Archaeological Reports.

SCHRÖTER, SUSANNE

1998 Death rituals of the Ngada in central Flores, Indonesia. Anthropos 93:417-435.

Sherman, George D.

1990 Rice, Rupees, and Ritual: Economy and Society Among the Samosir Batak of Sumatra. Stanford: Stanford University Press.

SimOONS, FREDERICK J.

1968 A Ceremonial Ox of India: The Mithan in Nature, Culture, and History. Madison: University of Wisconsin Press.

SJÖGREN, KARL-GÖRAN

1986 Kinship, labour and land in Neolithic Southwest Sweden: Social aspects of megalith graves. Journal of Anthropological Archaeology 5(3):229-265.

SMYTH, JESSICA

2010 The house and group identity in the Irish Neolithic. Proceedings of the Royal Irish Academy 111C:1-31.

Soejono, R. P.

1969 The history of prehistoric research in Indonesia to 1950. Asian Perspectives 12:69-91.

Steimer-Herbet, TARA

2018 Indonesian Megaliths: A Forgotten Cultural Heritage. Oxford: Archaeopress.

Steimer-Herbet, Tara, and Marie Besse

2016 Indonesian megaliths as the result of the interaction between indigenous peoples and HinduBuddhist kingdoms, in Austronesian Diaspora: A New Perspective. Proceedings of the International Symposium on Austronesian Diaspora: 301-318, ed. Bagyo Prasetyo, Titi Surti Nastiti, and Truman Simanjuntak. Djakarta: Gadjah Mada University Press.

THOMAS, JULiAN

1991 Rethinking the Neolithic. Cambridge: Cambridge University Press.

2016 House societies and the beginnings of the British Neolithic, in In Dialogue: Tradition and Interaction in the Mesolithic-Neolithic Transition: 3-10, ed. Jolene Debet, Mats Larsson, and Julian Thomas. BAR International Series 2809. Oxford: British Archaeological Reports.

Tringham, Ruth

1991 Households with faces: The challenge of gender in prehistoric architectural remains, in Engendering Archaeology: Women in Prehistory: 93-131, ed. Joan M. Gero and Margaret H. Conkey. Oxford: Blackwell Publishers.

Trostel, Brian

1994 Household pots and possessions: An ethnoarchaeological study of material goods and wealth, in Kalinga Ethnoarchaeology: Expanding Archaeological Method and Theory: 209-224, ed. William A. Longacre and James M. Sibo. Washington, D.C.: Smithsonian Institution Press.

van HeEkeren, Hendrik R.

1956 The urn cemetery at Melolo, East Sumba. Berita Dinas Purbakala 3:1-24.

Vel, Jacqueline A. C.

2008 Uma Politics: An Ethnography of Democratization in West Sumba, Indonesia, 1986-2006. Leiden: KITLV Press.

WATERSON, ROXANA

1990 The Living House: An Anthropology of Architecture in South-East Asia. Singapore: Oxford University Press. 
WiLK, RiCHARD R.

1983 Little house in the jungle: The causes of variation in house size among modern Kekchi Maya. Journal of Anthropological Archaeology 2:99-116.

1988 Maya household organization: Evidence and analogies, in Household and Community in the Mesoamerican Past: 135-151, ed. Richard R. Wilk and Wendy Ashmore. Albuquerque: University of New Mexico Press.

Wilk, Richard R., and William Rathje

1982 Household archeology. American Behavioral Scientist 25(6):617-639. 